\title{
39. PERMEABILITIES IN THE MIDDLE VALLEY HYDROTHERMAL SYSTEM MEASURED WITH PACKER AND FLOWMETER EXPERIMENTS ${ }^{1}$
}

\author{
Keir Becker, ${ }^{2}$ Roger H. Morin, ${ }^{3}$ and Earl E. Davis ${ }^{4}$
}

\begin{abstract}
We report the results of permeability measurements made during Ocean Drilling Program Leg 139 in two reentry holes drilled into the active hydrothermal system at the Middle Valley sedimented spreading center. Located in a vent field at the center of an elongate heat-flow anomaly, Hole $858 \mathrm{G}$ is cased to $270 \mathrm{mbsf}$ and penetrates $162.6 \mathrm{~m}$ deeper into igneous basement. About $1.6 \mathrm{~km}$ to the south, in the outer flank of the same heat-flow anomaly, Hole 857D is cased to $574 \mathrm{mbsf}$ and penetrates $362 \mathrm{~m}$ deeper into intercalated sills and sediments. The hydrogeological properties of the open-hole sections of both holes were assessed with two kinds of experiments using a drill-string packer to hydraulically isolate the hole: (1) standard slug and injection tests to measure average formation transmissivities and permeabilities, and (2) a new flowmeter/injection experiment to assess the fine-scale distribution of permeability. The results indicate that the lowermost $180 \mathrm{~m}$ of the sill/sediment sequence in Hole $857 \mathrm{D}$ and the upper igneous basement in Hole $858 \mathrm{G}$ both have average permeabilities on the order of $10^{-14} \mathrm{~m}^{2}$, similar to values obtained in the upper sections of basement in other holes drilled into young crust formed at unsedimented spreading centers. In addition, there are zones of exceptional hydraulic conductivity in the interval 610-685 mbsf in Hole 857D, with apparent permeabilities on the order of $10^{-10} \mathrm{~m}^{2}$. These zones allowed a huge flux of ocean bottom water down Hole 857D before the hole was sealed, at rates of about $10,000 \mathrm{~L} / \mathrm{min}$, two orders of magnitude greater than similar downhole flows observed in other young crustal holes. Our measurements represent the first determination of the characteristic hydrogeological properties of the kind of discrete faults, fractures, or other irregular zones of high hydraulic conductivity that are thought to control circulation patterns in active hydrothermal systems.
\end{abstract}

\section{INTRODUCTION}

Permeability, and its variation with both space and time, is perhaps the most important physical parameter controlling the patterns of circulation in an active hydrothermal system such as that drilled during Ocean Drilling Program (ODP) Leg 139 at Middle Valley, Juan de Fuca Ridge. However, it is difficult to directly determine the permeability of the oceanic crust and sediments and its scales of variability. No means of assessing ocean crustal permeability remotely have been proven accurate, and laboratory measurements on basement samples cannot represent in-situ permeability adequately because cored or dredged rocks do not sample the effects of large-scale fracture porosity and open faults. To date, the only reliable information about ocean crustal permeability comes from measurements made with drill-string packers in a few well-studied reentry holes (e.g., Anderson and Zoback, 1982; Hickman et al., 1984; Anderson et al., 1985; Becker, 1989, 1990, 1991).

We report here the results of permeability measurements made using drill-string packers in the two deep reentry holes drilled at the thickly sedimented spreading center in Middle Valley during Leg 139 (Fig. 1). Although located only $1.6 \mathrm{~km}$ apart, Holes $857 \mathrm{D}$ and $858 \mathrm{G}$ penetrate different types of basement. Hole $858 \mathrm{G}$ is located in an active vent field underlain by a basement high, where surface heat flow is extremely high, up to $20 \mathrm{~W} / \mathrm{m}^{2}$. The hole is cased to $270 \mathrm{~m}$ below seafloor (mbsf), through sediments and about $11 \mathrm{~m}$ of igneous basement, and then penetrates $162.6 \mathrm{~m}$ deeper into igneous basement comprising nearly continuous extrusive basalt flows. Hole $857 \mathrm{D}$ is located $1.6 \mathrm{~km}$ south of the vent field, away from the basement high, where heat flow is about $1 \mathrm{~W} / \mathrm{m}^{2}$. The hole is cased to $574 \mathrm{mbsf}$ through a 470-m-thick sediment section that grades into a sequence

\footnotetext{
${ }^{1}$ Mottl, M.J., Davis, E.E., Fisher, A.T., and Slack, J.F. (Eds.), 1994. Proc. ODP, Sci. Results, 139: College Station, TX (Ocean Drilling Program).

${ }^{2}$ Division of Marine Geology and Geophysics, Rosenstiel School of Marine and Atmospheric Science, University of Miami, Miami, FL 33149, U.S.A.

${ }^{3}$ U.S. Geological Survey, MS 403, Denver Federal Center, Denver, CO 80225 , U.S.A

${ }^{4}$ Pacific Geoscience Centre, Geological Survey of Canada, P.O. Box 6000, Sidney. British Columbia V8L 4B2, Canada.
}

of sills intercalated with sediments; below the casing, the hole penetrates $362 \mathrm{~m}$ deeper into a continuation of this sequence. Thus, the basement penetrated at Hole $858 \mathrm{G}$ might be considered analogous to oceanic basement at typical unsedimented ridges, whereas the sill/ sediment sequence penetrated at Hole $857 \mathrm{D}$ is similar to the formations penetrated by drilling at other sedimented spreading systems (e.g., the Guaymas Basin; Curray, Moore, et al., 1982).

Similar programs of downhole experiments were conducted at both of these reentry holes, including temperature and Schlumberger logging, the permeability measurements reported here, and the installation of instrumented borehole seals (Davis et al., 1992). Langseth and Becker (this volume) described the logging results, particularly with respect to the differences in basement character at the two holes. Davis and Becker (this volume) discussed the results from the instrumented borehole seals, which include long-term pressure data that relate directly to the permeability measurements reported here.

In both Holes $857 \mathrm{D}$ and $858 \mathrm{G}$, two kinds of permeability measurements were successfully conducted: (1) relatively standard packer experiments including slug and injection tests to assess the bulk permeabilities of the open-hole sections, and (2) a new kind of experiment involving logging with a flowmeter tool while constant-rate injection occurs in a section of hole isolated with the packer to assess the fine-scale distribution of permeability in the formation. We begin by describing these methods, then provide a detailed narrative of the experimental events, and finally discuss the results and compare the permeability information derived from Middle Valley to previous measurements in young, thinly sedimented oceanic crust.

\section{METHODS}

Both the standard packer tests and flowmeter experiment were conducted using a resettable drill-string packer manufactured by TAM International and described by Becker $(1986,1988)$. This packer incorporates inflatable rubber elements to isolate a section of the hole, and can be configured as a single or a straddle packer. For the measurements during Leg 139, it was configured with two adjoining elements and used as a dual-seal packer to isolate the zone between the dual-seal and the bottom of the hole (Fig. 2). The packer was deployed with two 

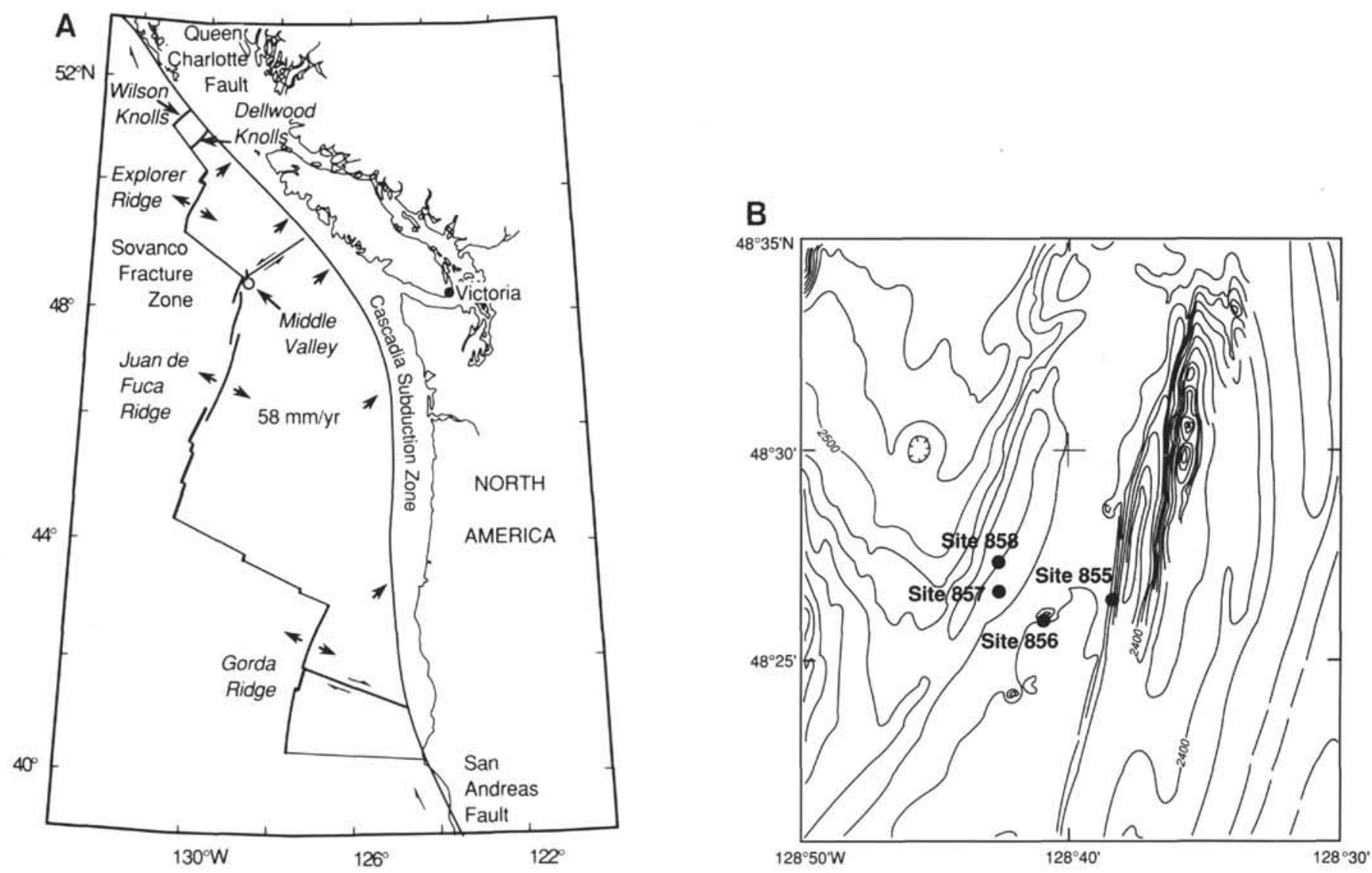

Figure 1. Location maps of (A) Middle Valley on the Juan de Fuca Ridge, and (B) the sites drilled in Middle Valley during Leg 139, with bathymetry contoured at intervals of $20 \mathrm{~m}$.

inflation elements instead of one in order to double its mechanical and hydraulic holding power when inflated in casing. In-situ temperatures in the deeper sections of both holes were predicted to approach $280^{\circ} \mathrm{C}$ (Davis and Becker, this volume), considerably higher than the packer seals were designed to withstand. Therefore, with one exception in Hole 857D, we followed a procedure of setting the packer about 100 $\mathrm{m}$ into casing, where temperatures were expected to be much cooler.

For both the standard packer experiments and the flowmeter experiment, key data were provided by sensors that measured fluid pressures in the zones isolated by the packer. Compared with previous ODP experience with packers, the pressures measured during Leg 139 were unusual in one important respect. As the holes were drilled with cold seawater into formations with steep geothermal gradients, there was a large differential between the "cold hydrostatic" pressures in the borehole and the "hot hydrostatic" formation pressure. This differential was both calculated and measured to be on the order of 1 $\mathrm{MPa}$ and is discussed in more detail by Davis and Becker (this volume). As will be seen in the following discussion, this resulted in large differences in the baseline pressures measured when the packer was inflated as opposed to when it was uninflated. It also resulted in significant differences in the pressures recorded by the downhole gauges as opposed to the rig floor gauges, with the latter always fixed to a near-atmospheric reference by the level of water maintained in the standpipe. These effects impacted the conduct of the experiments and particularly complicated the determination of proper reference pressures for interpretation of the results.

\section{Standard Packer Experiments}

When used for standard experiments to measure average formation permeabilities, the packer is actuated using a "go-devil" that is dropped down the drill string into the packer inflation subassembly. The go-devil also carries recorders to monitor downhole fluid pressures in the isolated, pressurized zone during the experiment; these pressures are the primary data from which permeability is calculated. Two types of downhole pressure recorders were used during Leg 139: (1) electronic "ERPG-300" gauges made by Geophysical Research Corporation (GRC), and (2) backup mechanical "K-3" gauges made by Kuster Company. The K-3 gauges record analog pressures mechanically by scratching a metal chart; the ERPG-300 gauges record in electronic memory 10000 digital pressure and temperature values sampled at 8.64-s intervals over one day. The data from these gauges were not available until the go-devil was retrieved upon completion of the experiment. However, the entire drill string as well as the isolated zone was pressurized during testing, and a 5000-psi (34.5Mpa) Gould pressure transducer at the rig floor was logged at 5-10-s intervals to provide a real-time record of downhole events. The data shown herein were obtained using the GRC downhole gauges and the Gould rig floor gauge. Throughout the packer measurements, pumping rates and total volumes pumped were also logged at the rig floor by monitoring the strokes of the mud pump. Pumping rates were recorded in units of strokes per minute (spm), with one stroke of the mud pump volumetrically equivalent to $19.7 \mathrm{~L}$ of seawater.

Once the packer was inflated, two kinds of experiments were used to determine the permeability of the isolated interval: pressure pulse or "slug" tests and constant-rate injection tests. The procedures required for inflation of the packer always resulted in an initial slug test when the packer was locked in the inflated position. The methods used were similar to those described by Anderson and Zoback (1982), Hickman et al. (1984), Anderson et al. (1985), and Becker (1989, $1990,1991)$ in conducting previous packer experiments in Holes $395 \mathrm{~A}, 504 \mathrm{~B}$, and $735 \mathrm{~B}$. Injection tests generally disturb the pressure 
field in the formation around the hole much more than slug tests and were therefore conducted after the slug tests at appropriate inflation depths. When a sequence of tests was conducted at a single inflation depth, the data from each test were corrected for the extrapolated decay(s) of the previous test(s). In addition, owing to the large differential between the fluid pressure in the borehole and the formation pressure described previously, careful interpretation of and corrections to the measured pressures were required, as is described more fully in the following.

\section{Slug Test Procedures}

The slug tests were conducted following the methods for the "modified" slug test of Bredehoeft and Papadopulos (1980), which is an adaptation of the slug test method of Cooper et al. (1967) and Papadopulos et al. (1973) for formations with relatively low permeabilities. In the modified slug test, a short pressure pulse is applied to the fluid in the zone isolated by the packer, and the decay of this pulse is monitored as fluid flows from the pressurized borehole into the isolated formation. The decay of such a pressure pulse is described by the equation

$$
P(t) / P_{0}=F(\alpha, \beta)
$$

where $P$ is pressure in excess of the initial undisturbed value, $P_{0}$ is the initial pressure increase, $\alpha$ is a dimensionless parameter that depends on the storage coefficient $(S)$ and porosity $(\phi)$ of the isolated formation, $\beta$ is a dimensionless parameter that depends on the transmissivity $(T)$ and permeability $(k)$ of the formation, and $F$ is a complicated infinite integral. More specifically,

$$
\begin{gathered}
\alpha=\pi a^{2} S / V_{w} C_{w} \rho_{w} g, \\
\beta=\pi T t / V_{w} C_{w} \rho_{w} g, \\
S=b \phi C_{i} \rho_{i} g, \text { and } \\
T=b k \rho_{i} g / \mu,
\end{gathered}
$$

where $t$ is time, $g$ is gravitational acceleration, $a$ is the radius of the hole in the isolated zone, $b$ is the height of the isolated zone, $C_{i}, \rho_{i}$, and $\mu$ are respectively the compressibility, density, and dynamic viscosity of the fluid in the isolated zone, and $C_{w}$ and $\rho_{w}$ are the compressibility and density of the fluid in the total pressurized volume $V_{w}$. (Note that the total pressurized volume $V_{w}$ includes the rig floor plumbing and drill string in addition to the zone isolated below the packer.)

To process the pressure data measured during slug tests, we followed the standard curve-fitting method described by Cooper et al. (1967) and Papadopulos et al. (1973). A plot of the decay of measured pressures vs. log time was superposed on a family of type curves of $F(\alpha, \beta)$ vs. $\log \beta$ calculated for various values of $\alpha$ spanning several orders of magnitude. The data plot was then shifted along the abscissa of the type-curve plot to visually determine the value of $\alpha$ for which the data best fit the type curve. Then the transmissivity and average permeability of the tested interval could be calculated from the correspondence between the values of time and $\beta$ for the best-fit curve, using the definitions for $\beta$ and transmissivity given in equations (3) and (5).

As noted by Cooper et al. (1967), Papadopulos et al. (1973), Bredehoeft and Papadopulos (1980), and Hickman et al. (1984), the calculated type curves are relatively insensitive to changes in $\alpha$ and much more sensitive to changes in $\beta$. Thus, this procedure yields relatively poor estimates of the storage coefficient and porosity, but reasonable determinations of transmissivity and average permeability. Even where there are differences between borehole hydrostatic pressures and formation pressures, as in our experiments, Coyle and

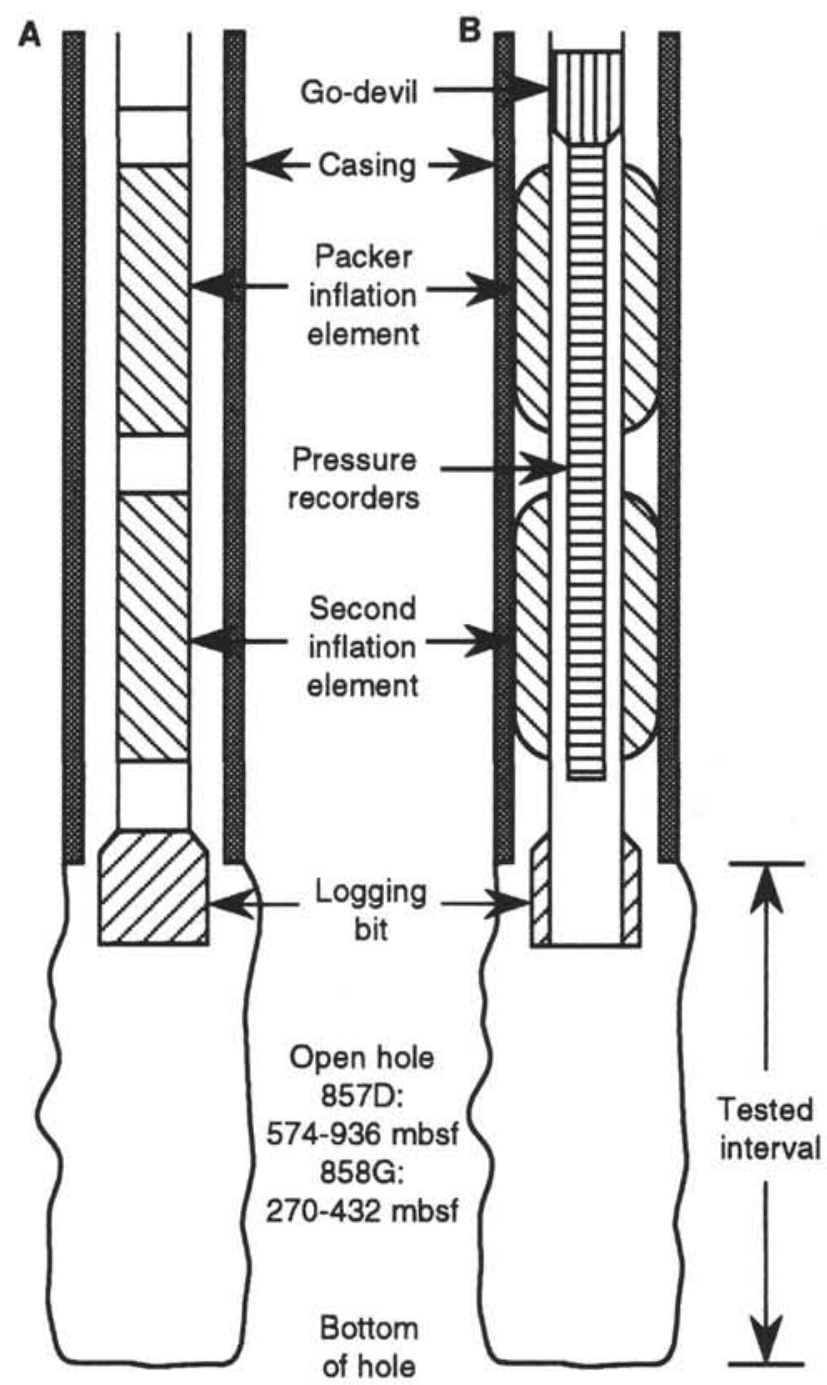

Figure 2. Sketch of the inflatable drill-string packer as deployed during Leg 139. A. The dual-element packer incorporated in the bottom-hole assembly, before inflation or after deflation. B. Cut-away sketch of the inflated packers showing go-devil, pressure recorders, and tested interval between the casing shoe and the bottom of the hole. During inflation of the packer, the go-devil directs fluids pumped from the rig floor into the inflation elements. Once the packer is inflated, the go-devil position is shifted such that fluids pumped from the rig floor are directed into the tested interval.

Zoback (1988) showed that (1) the early slug test data reliably determine the proper type curve, and (2) the later slug test data are sensitive to the proper choice of a reference pressure.

\section{Constant-rate Injection Tests}

In a relatively permeable formation, a slug test will decay quite rapidly; a better determination of permeability can be obtained by conducting a constant-rate injection test. In this experiment, borehole pressure within the isolated zone is monitored as fluids are pumped into the formation at a constant rate. As long as injection rates are kept sufficiently low as to not hydrofracture the formation, the rise of pressure as injection proceeds quickly becomes linear with the log of time, according to the following equation (Horner, 1951; Matthews and Russell, 1967):

$$
P\left(t_{i}\right)=(q \mu / 4 \pi k b) \ln \left(\gamma \phi \mu C_{i} a^{2} / 4 k t\right)
$$


where $P$ is the pressure increase over the in-situ formation pressure, $t_{i}$ is time since the start of injection, $q$ is the constant flux of injected fluids, $\gamma$ is Euler's constant, and the remaining parameters are defined previously. When the injection is stopped, and if the hole is "shut in" such that pressures are not vented at the rig floor, pressures will decay towards in-situ pressures according to the classic "Horner" equation:

$$
\mathrm{P}\left(t_{s}\right)=(-q \mu / 4 \pi k b) \ln \left(t_{i} / t_{s}\right)
$$

where $t_{s}$ is time since the end of injection and beginning of shut in, and $t_{i}$ remains time since the beginning of injection.

Thus, the average permeability of the isolated zone can be determined in two ways from an injection test: (1) directly from the slope of a plot of pressure vs. In time during injection at a measured constant rate, and (2) from the slope of a similar plot of the decay of pressures vs. $\ln \left(t_{i} / t_{s}\right)$ in the shut-in hole after injection is stopped. These should yield similar results; if not, it may indicate that during injection the pressurized fluids either leaked past the packer seal or opened preexisting cracks in the formation to effectively increase permeability. If pressures during injection quickly reach a nearly steady-state value, permeability may also be estimated using Glover's formula (Snow, 1968), which results from a steady-state approximation to the injection equation (6):

$$
k=(q \mu / 2 \pi b \Delta P) \ln (b / a)
$$

where $\Delta P$ is the nearly steady-state pressure increase and the remaining parameters are as defined previously.

\section{In-situ Permeability vs. Calculated Bulk Permeability}

Both slug and injection tests involve an important assumption: that the permeability of the rock in the zone isolated by the packer is uniform and isotropic. This assumption is certainly not valid for some of the formations penetrated during Leg 139, where, as will be demonstrated in the following discussion, the transmissivity may be dominated by discrete zones with high hydraulic conductivity. Nevertheless, where the packer isolated sections not including such discrete conductive zones, the assumption probably "becomes more valid as the scale of the permeability tests [i.e., the length of the zone isolated by the packer] increases with respect to the spacing of the fractures" (quoting from Hickman et al., 1984; see also Parsons, 1966). The permeabilities computed here are average Darcian or equivalent porousmedium permeabilities, denoted as bulk permeabilities, obtained by applying the theory for uniformly permeable media. If the actual permeability structure is indeed dominated by isolated fractures, the hydraulic conductivities of such fractures may be orders of magnitude greater than the values reported here.

\section{Properties of the Fluids in the Pressurized System}

The transient pressures measured during both slug and injection tests depend on the properties of the pressurized fluids, particularly viscosity and compressibility, which vary with both temperature and pressure. For the temperature-dependent viscosity of seawater, we used two relationships: (1) for temperatures less than $25^{\circ} \mathrm{C}$, we interpolated among oceanographic values given by Sverdrup et al. (1942, p. 69) and (2) for temperatures greater than $25^{\circ} \mathrm{C}$, we used Gartling's (1977) empirical equation, $\mu\left(10^{-3} \mathrm{~Pa}-\mathrm{s}\right)=16.68 T^{-0.8987}$, with $T$ in ${ }^{\circ} \mathrm{C}$. Actual temperatures in the zones pressurized during the packer experiments ranged from bottom-water values to formation values, and appropriate average values for the pressurized intervals had to be estimated. These values were estimated using the sensors in the GRC recorders, which generally indicated that the greater proportions of the isolated sections were kept quite close to ocean bottomwater temperatures.
As noted by Neuzil (1982), the effective compressibility of the fluid in a shut-in hole is sometimes greater than that of the pure fluid (seawater in this case), because of (1) compliance of the drill string and test equipment and (2) air possibly trapped in the system. While every effort was made during Leg 139 to purge all air from the drill string, pump, and connecting plumbing, small amounts of air may have remained in the system. Such trapped air would increase the effective system compressibility and cause the transmissivity and bulk permeability calculated in a slug test to be erroneously low. Therefore, we carefully recorded the volumes pumped downhole during slug tests, so that the effective compressibility of the pressurized system could be determined using the definition of compressibility, $C=\mathrm{d} V / V \mathrm{~d} P$, and then be used in the calculation of formation permeability. This was not possible for the initial slug test that occurred automatically on packer inflation, as it was impossible to distinguish what proportion of the pumped fluids went into the packer elements as opposed to being applied to the isolated zone as a pressure pulse.

\section{Flowmeter/Injection Experiment}

The flowmeter/injection experiment was run to assess the finescale variation of permeability and the contribution of faults and fractures to the bulk values measured with the packer. The flowmeter/ injection method utilizes constant-rate injection into a hole sealed by the packer and simultaneous logging of pressure, downhole flow, and hole size with depth to arrive at a detailed vertical profile of hydraulic conductivity. The field method was originally proposed by Hufschmied (1984) and has been evaluated and successfully conducted in subaerial holes (e.g., Morin et al., 1988; Hess, 1989; Molz et al., 1989). The modifications necessary for use on a drill ship with no well control had been partially tested during Leg 137 (Becker, Foss, et al., 1992).

Fundamental differences exist between the way this experiment is performed in a subaerial hole and the way it must be performed in an ODP hole. In the former case, all fluid injected into the hole at the well head can be assumed to enter the formation. In the ODP case, fluid injected from shipboard pumps down the drill string may escape back up the annulus to the open ocean unless a packer is used to seal the annulus (Fig. 3). Adapting this experiment for ODP use required designing a new packer go-devil that would ride on the logging cable as the flowmeter tool was lowered into the hole before packer inflation. This go-devil was required first to enable packer inflation, and then to release the logging cable so the flowmeter log could be conducted as fluid was injected into the formation.

The flowmeter tool used for the experiment (Fig. 3) was built by Comprobe and incorporated a pressure sensor with a range of 10,000 psi (68.9 MPa), spinner flowmeter, and a caliper with a maximum reading of 15 -in. hole diameter. The nominal resolution of the pressure sensor is $0.01 \%$ of the full-scale reading. The range and resolution of the spinner flowmeter depend on the diameter of the hole and require calibration at the beginning of the experiment by pumping at known rates while the tool remains stationary in the casing. The 11-3/4-in. casing diameter provided reasonable calibration conditions for the flowmeter response in the 10-15-in. diameter hole generally produced with the standard 9-7/8-in. ODP roller-cone bit used to drill both Holes 857D and 858G.

The flowmeter/injection experiment was envisioned to involve continuous logging of the hole during constant-rate injection, yielding a continuous record of the variation of borehole fluid pressure, horizontal flow rates into the formation, and hole size with depth. These data were to be converted to a log of hydraulic conductivity and permeability with depth, using steady-flow approximations described by Cooper and Jacob (1946). However, the actual field method employed during Leg 139 involved stationary measurements at discrete depth intervals at specified injection rates, because it was not possible to simultaneously pump down the hole and troll the flowmeter with- 
out inducing significant fluid losses at the rig-floor seal around the logging cable.

In addition, two special circumstances also affected the conduct of the flowmeter experiments during Leg 139. First, the differential pressure between the cold injected fluids and hot formation fluids was so great that it was virtually impossible to resolve the much smaller changes in head needed to convert the variations in downhole flow to hydraulic conductivities and permeabilities. Second, the wireline heave compensator was unavailable for Leg 139; as a result, considerable noise was introduced into the spinner readings and there was especially poor resolution at low flow rates. The data shown below were obtained by low-pass filtering the noisy readings to minimize the effects of heave on the spinner readings. Because of these limitations, the data did not justify conversion to a detailed permeability $\log$, but instead were used to pinpoint zones of significant hydraulic conductivity. Nevertheless, as described below, the qualitative observations of the variations in downhole flow rate with depth were so striking that the experiment proved an important success.

\section{NARRATIVE OF THE EXPERIMENTS}

\section{Packer and Flowmeter Experiments in Hole 857D}

The packer and flowmeter experiments in Hole 857D were conducted after the hole had been cased to $574 \mathrm{mbsf}$ and deepened to 936 mbsf. The purpose of the experiments was to assess the variation of permeability through the open-hole interval of 574-936 mbsf, which consists of a sequence of intercalated sills and sediments. Four godevils were deployed, and the packer was inflated six times (including two repeated inflations when the packer inadvertently deflated owing to ship's heave) at two depths during a $27-\mathrm{hr}$ sequence that included standard packer experiments and the flowmeter experiment. When it was retrieved, the first go-devil was found to be plugged with a mixture of grease and rust flakes from the inside of the drill string, which invalidated the results of the permeability tests although the packer itself operated properly. The pressure record from this go-devil is not shown here, but was presented by Shipboard Scientific Party (1992a, p. 413). Figure 4 summarizes the sequence of successful experiments with respect to the lithology and logs in Hole 857D.

\section{Second Go-Devil, Packer at $96 \mathrm{mbsf}$}

After the first go-devil was found to have been fouled with rust, a "pig" was pumped down the pipe to clean it of rust, and the packer experiment was repeated at the same inflation depth. A second go-devil was deployed with redressed Kuster and GRC pressure recorders, and the packer was inflated in casing to $1800 \mathrm{psi}(12.4 \mathrm{MPa})$. Figure 5 shows the pressure records collected during the ensuing test sequence. Two slug tests were attempted, but the pressure pulses decayed extremely rapidly and can barely be distinguished on the downhole pressure record. The rapid decays of the pressure pulses seen on the rig floor gauge indicated that the formation was indeed very transmissive, so constant-rate injection tests were attempted. Injection was started at $38 \mathrm{spm}$, but no pressure rise was observed on the surface gauges, so the pump rate was gradually increased. After the injection rate reached $80 \mathrm{spm}$, a small pressure rise was observed, so the pumps were held constant at this rate for $10 \mathrm{~min}$ and then the hole was shut in, as in a standard constant-rate injection test. Pressure decayed immediately at the surface, and two more injection tests were conducted, at rates of 100 and $140 \mathrm{spm}$. Although the latter was close to the maximum that the ship's pumps could deliver, Fig. 5 shows that the downhole pressure increase was quite small compared to the difference between the formation pressure and the cold hydrostat in the borehole. The small pressure increases at large injection rates, and immediate pressure decays on shut in after pumping, indicated that the average permeability of the formation was high, probably orders of magnitude greater than any value previously measured in any Deep Sea Drilling Project (DSDP) or ODP hole. This go-devil also gave an indication of the

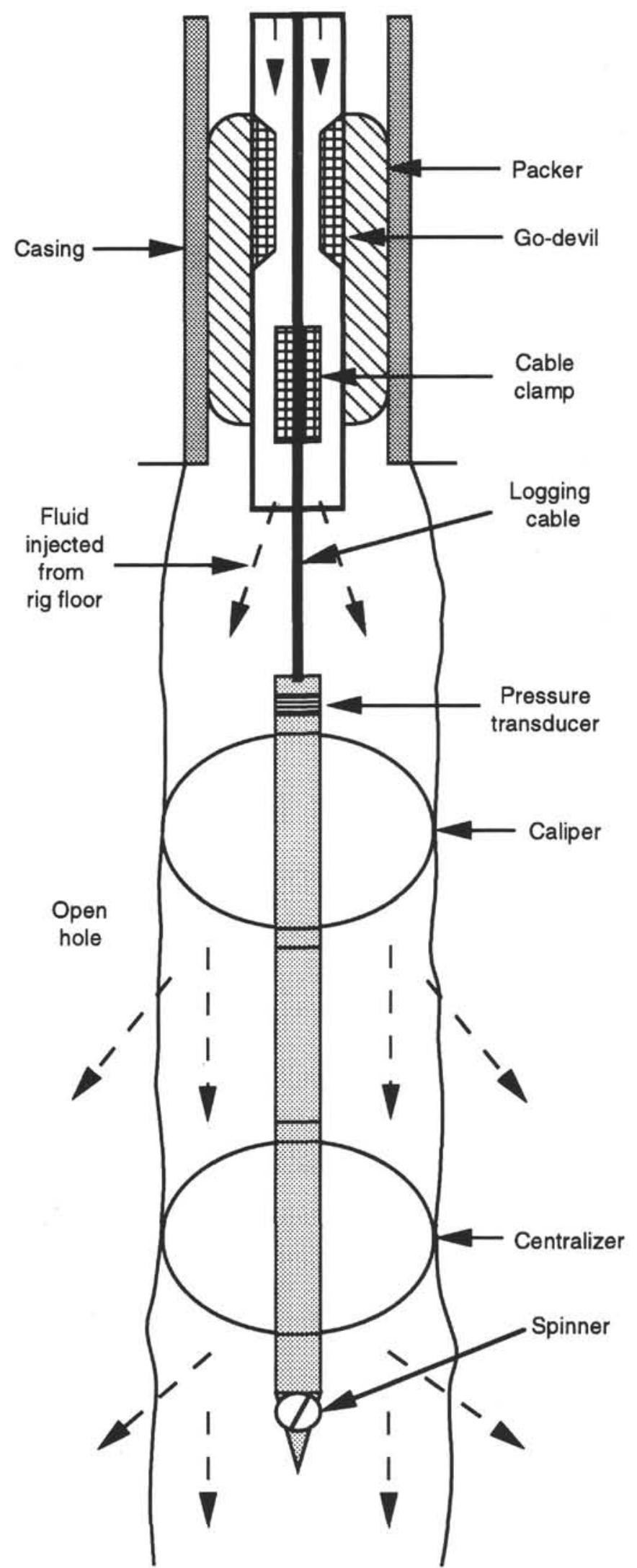

Figure 3. Sketch of the flowmeter/injection experiment after inflation of the packer. The packer is shown schematically with a single element, although two elements were used as shown in Fig. 2. Dashed lines with arrows represent fluids pumped from the rig floor and into permeable zones of the formation. 


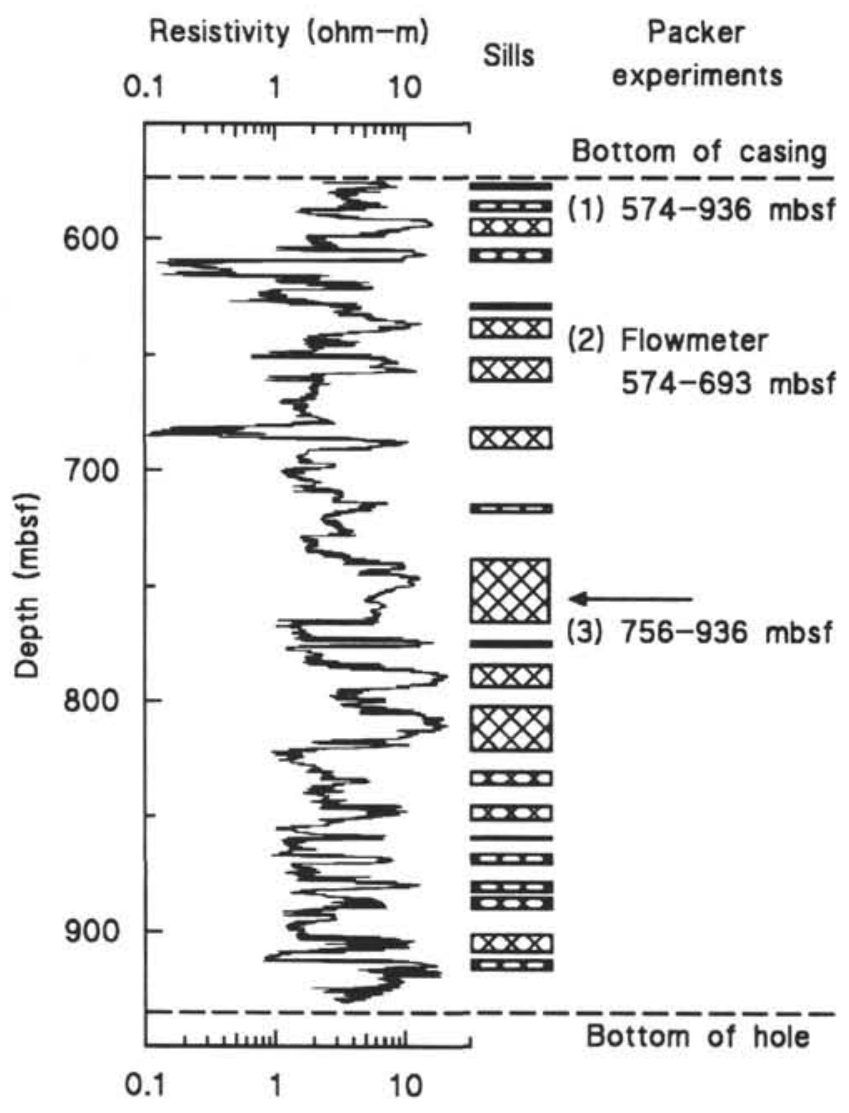

Figure 4. Summary of the sequence of packer and flowmeter measurements conducted in Hole 857D, along with the resistivity log and a sequence of sills interpreted from the resistivity and gamma-ray logs (Shipboard Scientific Party, 1992a). In the column on the right, the parenthesized numbers (1-3) denote the sequence of successful packer experiments, with the depth ranges denoting the intervals over which the respective experiments were conducted. For the first and second experiments, the packer was inflated at $96 \mathrm{mbsf}$ within casing, but the test interval began at 574 mbsf or the bottom of the casing; for the third experiment, the packer was inflated at 756 mbsf, in a thick sill at the position shown by the horizontal arrow.

differential between the formation pressure and the cold hydrostat in the borehole, which was on the order of $1 \mathrm{MPa}$.

\section{Third Go-Devil and Flowmeter Experiment, Packer at 96 mbsf}

The high transmissivity of the formation provided nearly ideal conditions for the flowmeter/injection experiment. The packer was left uninflated in position in the casing, and the flowmeter tool and logging cable go-devil were run into the hole. After the packer was inflated, the flowmeter was first lowered to near the bottom of casing, at which point the ship's pumps were used to calibrate the spinner reading in the casing at several flow rates. Heave introduced significant noise in the spinner readings, particularly at low flow rates. The flowmeter was then run into the hole for stationary measurements at 10 - $\mathrm{m}$ intervals while the mud pumps were turned up to the maximum steady injection rate, $150 \mathrm{spm}$ (Fig. 6). Within $60 \mathrm{~m}$ below the bottom of the casing, the flowmeter readings dropped so low relative to the noise introduced by heave that no reliable information would have been collected by continuing any deeper. The tool was then raised back into the casing, where the flowmeter was recalibrated within casing at a pump rate of $150 \mathrm{spm}$, and the packer was deflated.

As soon as the packer deflated, the spinner reading more than tripled, indicating that the differential between the cold hydrostat and formation pressure was so great, and the formation so transmissive, that the formation was drawing bottom water at roughly three times

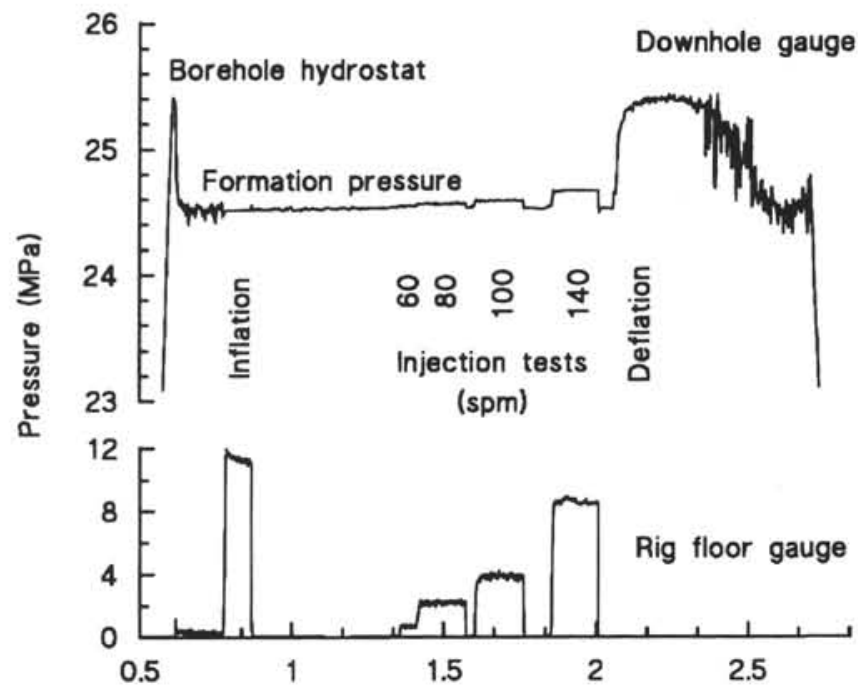

Time since downhole gauge started (hr)

Figure 5. Annotated pressure-time records collected downhole and at the rig floor during the standard packer experiments conducted in Hole 857D with the packer set in casing at 96 mbsf, testing the entire open-hole interval of 574-936 mbsf.

the maximum rate that the ship's pumps could deliver. Given that the formation was drawing bottom water so strongly, the packer and ship's pumps were actually unnecessary for the experiment, and the $\log$ was repeated at intervals of $10-20 \mathrm{~m}$ utilizing the induced flow down the hole. With the larger injection rate, the flowmeter gave valid readings down to about $120 \mathrm{~m}$ below the base of the casing, by which point most of the massive downhole flux had been diverted into the formation. The flowmeter was then pulled back into the casing for a final calibration, and the experiment was ended.

\section{Fourth Go-Devil, Packer at 756 mbsf}

The flowmeter experiment had shown that most of the extraordinary downhole flow in Hole 857D was diverted into the upper section of open hole, and that this section of the hole was maintained at temperatures nearly as low as bottom-water values because of the downhole flow. Therefore, it was decided that it was both technically feasible and scientifically interesting to run the packer below this zone and measure the permeability of the deeper section of open hole. The packer was run to $756 \mathrm{mbsf}, 180 \mathrm{~m}$ above the bottom of the hole, and inflated at the center of the thickest sill cored in Hole 857D. Previous logs had indicated that the hole in this interval is particularly smooth and round. Figure 7 shows the record of testing during this packer inflation. Two slug tests were attempted, including the slug test that automatically occurs when the packer is inflated. While attempting to pump the pressure pulses for the inflation and slug tests, the drillers noted that a significant volume of fluid had to be pumped to first "fill the pipe." Pressure readings at the surface decayed quickly, and two constant-rate injection tests were conducted. The injection tests showed that this lowermost section of hole is significantly less permeable than the open-hole formations above, although it is still roughly as permeable as the upper sections of basement in Holes 504B and 395A (Anderson and Zoback, 1982; Becker, 1990).

When the downhole gauges were recovered, they showed longer decay periods for both the slug tests and injection tests than the rapid decays seen on the surface gauges, because of the difference between the cold hydrostatic pressure in the borehole and the formation pressure. As this pressure differential is probably quite large, the fact that measurable downhole flow does not appear to extend to the deeper part of the hole supports the conclusion that this section is significantly less permeable than the upper $100 \mathrm{~m}$ of open hole. The two slug 


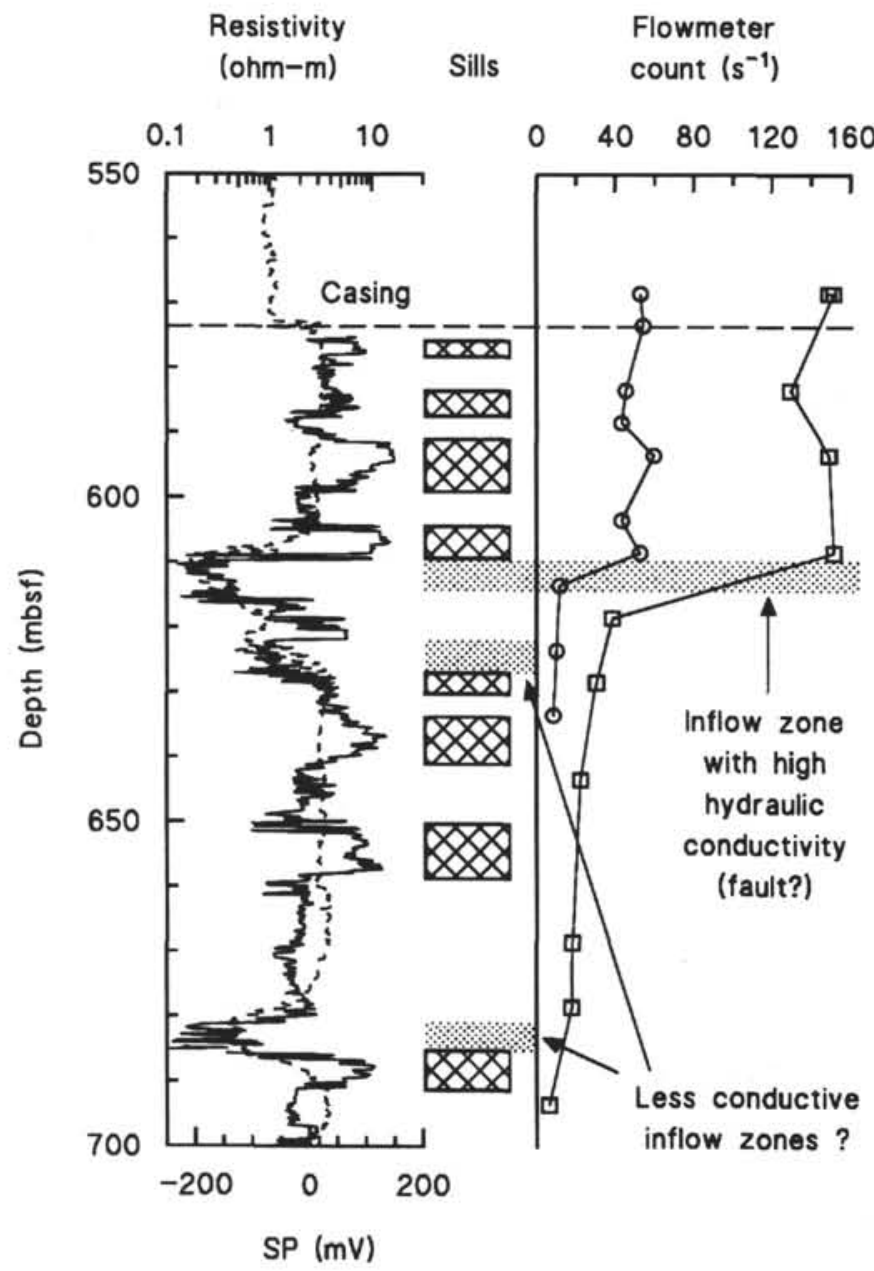

Figure 6. Summary of the results of the flowmeter experiment in Hole 857D. The left and center columns show an expanded view of the logs of resistivity (solid line) and spontaneous potential (dashed line), along with the interpreted sills as shown in Fig. 4. The right column shows the variation of downhole flow readings collected during the flowmeter experiment in Hole 857D. Circles denote average readings collected with the packer inflated and the ship's pumps injecting $150 \mathrm{spm}$; squares show readings after the packer was deflated and ocean-bottom water was flowing down the hole.

tests are not reliable because they show irregular decay curves, probably related to the reason that large volumes had to be pumped to produce the pressure pulses. The two injection tests, particularly the second, appear to be of good quality and are analyzed herein to determine the permeability of the lower section of the hole.

\section{Packer and Flowmeter Experiments in Hole 858G}

Packer and flowmeter experiments were conducted in Hole 858G after it had been cased to $270 \mathrm{mbsf}$ and deepened to $432.6 \mathrm{mbsf}$; the open-hole section comprises a nearly continuous sequence of basaltic flow units. Three go-devils were deployed, and the packer was inflated three times within casing during a sequence of standard permeability tests and the flowmeter experiment. As at Hole 857D, the first go-devil was fouled with rust and provided little useful data; the pressure record from this go-devil was shown and discussed by Shipboard Scientific Party (1992b, p. 561).

\section{Second Go-Devil, Packer at $104 \mathrm{mbsf}$}

To minimize further problems related to rust in the pipe, the godevil was modified to ensure the largest possible flow passages, and

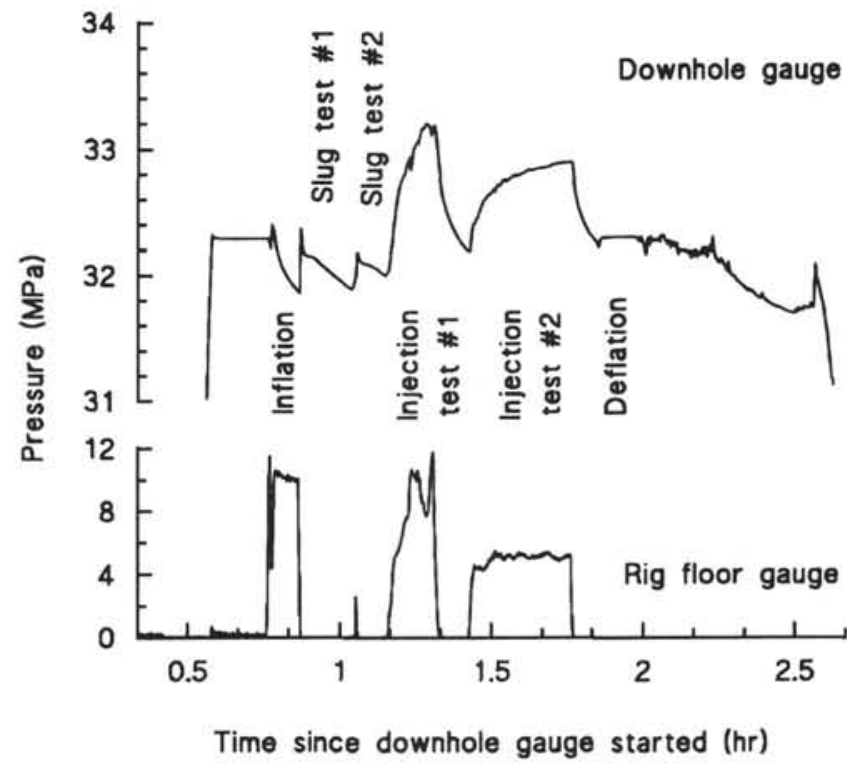

Figure 7. Annotated pressure-time records collected downhole and at the rig floor during the standard packer experiments conducted in Hole 857D with the packer set in a thick sill at 756 mbsf, testing the zone 756-936 mbsf.

the packer experiment was repeated at the same inflation depth. The modified go-devil was deployed with redressed Kuster and GRC pressure recorders, and the packer was inflated at $1500 \mathrm{psi}(10.3 \mathrm{MPa})$. A temperature log conducted immediately after retrieval of the rustfouled first go-devil had shown evidence suggestive of some flow of ocean bottom water down the hole, indicating significant permeability in the formation, and the test sequence was conducted accordingly.

Figure 8 shows the pressure record collected during this test sequence. First, two slug tests were conducted, producing moderate decay curves, and then four injection tests were conducted at successively higher pumping rates. The pressure records from the first three slug and injection tests appear to be of good quality and are processed herein to estimate the bulk permeability of the open-hole section. However, the data from the last three injection tests deviate from the ideal record, in which pressure should increase monotonically with time towards a nearly steady-state value (Horner, 1951; Matthews and Russell, 1967). In contrast, these records show noticeable decreases of pressure at long injection times preceding the smooth decays when pumping was stopped (Fig. 8). They also show pressure spikes at the beginning of each injection test. The combination of effects is similar to that observed in a hydrofracture experiment when pre-existing cracks are reopened under the pressure of constant-rate injection (e.g., Hickman and Zoback, 1983). Thus, it appears that an inadvertent hydrofracture experiment was conducted beginning with the second injection test, with pre-existing cracks opened such that any permeabilities calculated from the last three injection tests would probably be unrepresentative of the formation.

\section{Third Go-Devil and Flowmeter Experiment, Packer at 104 mbsf}

The moderate permeability of the formation provided a good test of the resolution of the flowmeter/injection experiment, which had been run under conditions of exceptionally vigorous downhole flow in Hole $857 \mathrm{D}$. The packer was left uninflated in position in the casing, and the flowmeter tool and logging cable go-devil were run into the hole. After the packer was inflated, the flowmeter was first lowered to near the bottom of casing, and the ship's pumps were used to calibrate the spinner reading at known flow rates. At given pumping rates, pressures rose much more than at Hole 857D because the formation is less transmissive in Hole 858G. At the higher injection rates there was significant leakage of the pumped fluids at the gland on the top drive 


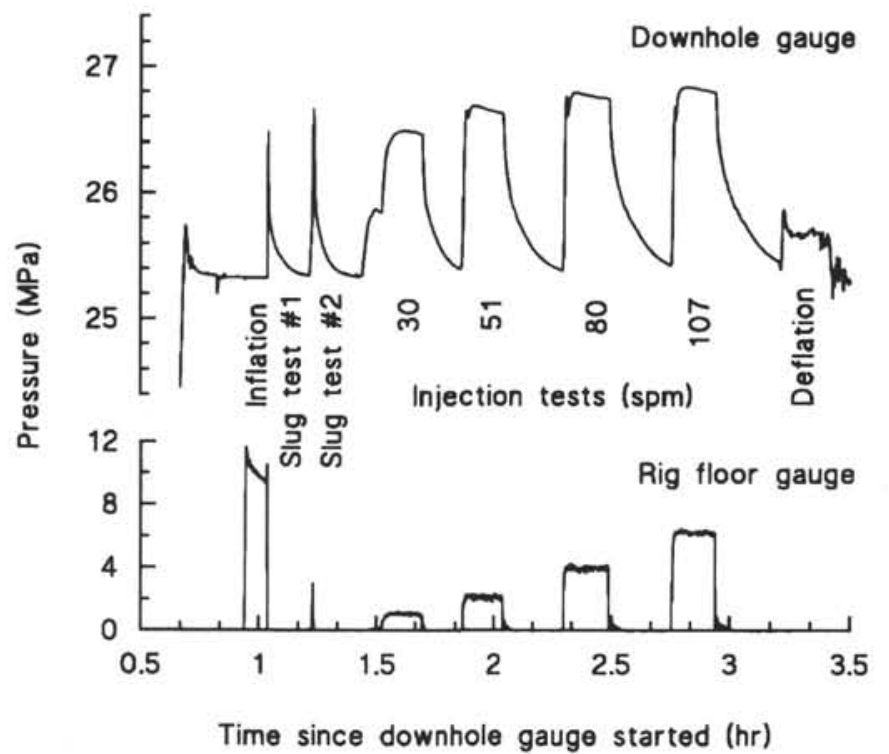

Figure 8. Annotated pressure-time records collected downhole and at the rig floor during the standard packer experiments conducted in Hole $858 \mathrm{G}$ with the packer set in casing at 104 mbsf, testing the entire open-hole interval of $270-432.6$ mbsf.

that sealed the logging line. Because of this effect, injection rates had to be kept lower than in Hole $857 \mathrm{D}$, and the resolution of the flowmeter was limited for the experiment in Hole 858G.

The flowmeter was then run into the hole for stationary measurements at 10-m intervals (Fig. 9). At the first measurement depth, an injection rate of $100 \mathrm{spm}$ was attempted, but fluid leakage at the rig floor seal on the logging line was unacceptable, so the experiment was conducted at $50 \mathrm{spm}$ (one-third the rate that had been used in Hole $857 \mathrm{D})$. Within $80 \mathrm{~m}$ below the bottom of the casing, the flowmeter readings dropped so low relative to the noise introduced by heave that no reliable information would have been collected by continuing any deeper. The tool was then raised back into the casing, where it was recalibrated at a pumping rate of $50 \mathrm{spm}$, and the packer was deflated. After deflation, the flowmeter reading showed no indications of detectable downhole flow, in contrast to the vigorous downhole flow observed in Hole 857D, and the experiment was ended.

\section{DATA INTERPRETATION AND RESULTS}

\section{High Hydraulic Conductivity in the Upper Open-hole Section of Hole 857D}

As described previously, the pressure records from the standard packer tests of the entire open-hole interval in Hole 857D (Fig. 5) showed only small pressure increases during injection tests at high rates, indicating that the formation included zones of exceptionally high hydraulic conductivity. The record of the subsequent flowmeter experiment (Fig. 6) strongly indicates that the bulk of the hydraulic conductivity is concentrated in a few narrow zones, with one dominant zone at 610-615 mbsf and perhaps two less conductive zones at about $620-625$ and $680-685 \mathrm{mbsf}$. Thus, it is clearly inappropriate to interpret the records of the standard injection tests in terms of an average permeability of the entire open-hole interval, when the results were so dominated by the hydraulic properties of these thin formations.

With the packer sealing the annulus, the flowmeter was calibrated in casing at flow rates up to the maximum the ship's pumps could deliver, $150 \mathrm{spm}$. When the packer was deflated at the end of the flowmeter experiment, the spinner signal level in the cased section was three times as great as the level at the maximum calibration pump rate. The calibration data suggest that the spinner count is slightly nonlinear

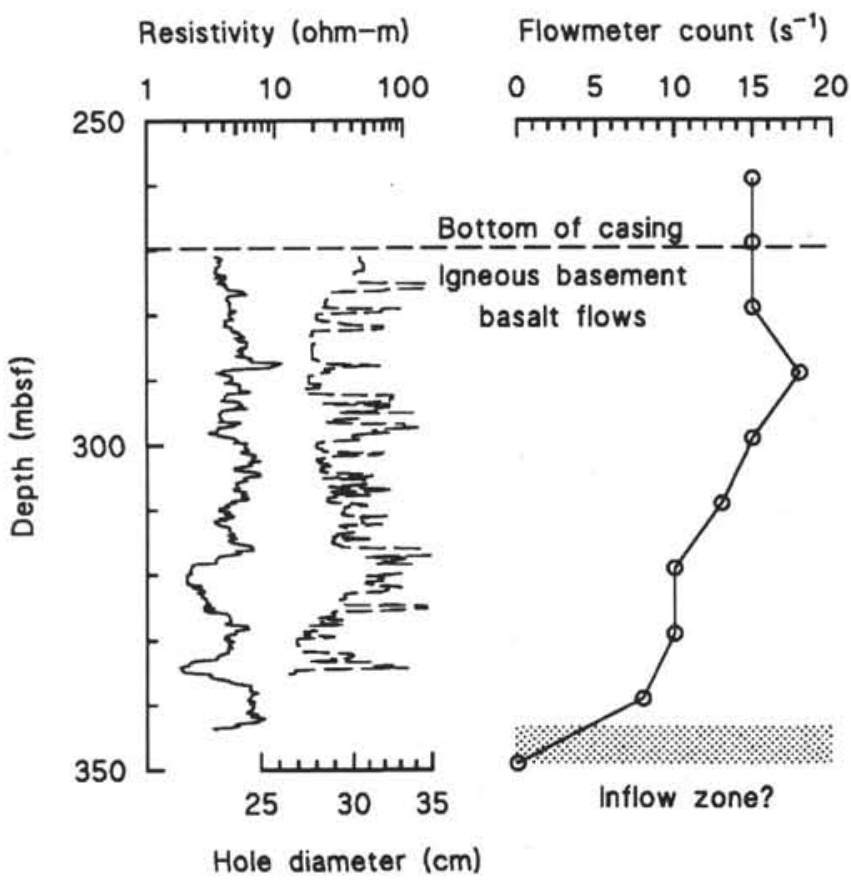

Figure 9. Summary of the results of the flowmeter experiment in Hole 858G. The plot on the left shows the resistivity (solid line) and caliper (dashed line) logs. The plot on the right shows the variation of downhole flow readings collected during the flowmeter experiment in Hole $858 \mathrm{G}$, with the ship's pumps injecting $50 \mathrm{spm}$ into the open-hole section.

with flow rate, and we can only crudely estimate the rate of natural downhole flow beyond the calibration range. The estimated rate at which the formation was naturally drawing fluids is equivalent to 400 $500 \mathrm{spm}$, or nearly $10,000 \mathrm{~L} / \mathrm{min}$. This rate is at least two orders of magnitude greater than the rates of the long-lived downhole flows observed during postdrilling reentries of Holes 395A and 504B (Fig. 10) (Becker et al., 1983, 1984; Kopietz et al., 1990; Morin et al., 1992).

The zone at about $610-615$ mbsf clearly accepted most of the downhole flow, and is marked by negative anomalies in both the resistivity and spontaneous potential (SP) logs. Similar anomalies appear at 620-625 and 680-685 mbsf, and these zones are also associated with small decreases in the spinner counts; these zones are therefore interpreted here as possible hydraulically conductive zones. Almost no core was recovered from these sections, so there is little information as to their nature. In fact, unusual events occurred when the dominant conductive zone at $610-615$ mbsf was first penetrated, including rapid advance of the bit and a sudden loss of fluid level in the drill pipe (Shipboard Scientific Party, 1992a). This suggests that the downhole flow of bottom water began at that time, driven by the differential pressure between the cold drilling fluids and hot formation fluids, and enabled by the high hydraulic conductivity at that depth in the formation.

Because the zone at $610-615 \mathrm{mbsf}$ accepted most of the downhole flow during the flowmeter experiment, it probably accepted nearly all of the lesser fluxes applied during the constant-rate injection tests conducted with the packer inflated in casing (Fig. 5). Thus, we can estimate the transmissivity of this zone from the pressure increases observed during the constant-rate injection tests, particularly those conducted at the higher rates of 80,100 , and $140 \mathrm{spm}$. In all three cases, the pressure increases quickly approached nearly constant values, so we estimated the transmissivity using the steady-state Glover approximation described previously. The results (Table 1) indicate a transmissivity of about $2 \times 10^{-3} \mathrm{~m}^{2} / \mathrm{s}$; if the thickness of the zone is taken as $5 \mathrm{~m}$, this is equivalent to a hydraulic conductivity of about 4 $\times 10^{-4} \mathrm{~m} / \mathrm{s}$ and an apparent permeability on the order of $10^{-10} \mathrm{~m}^{2}$. 


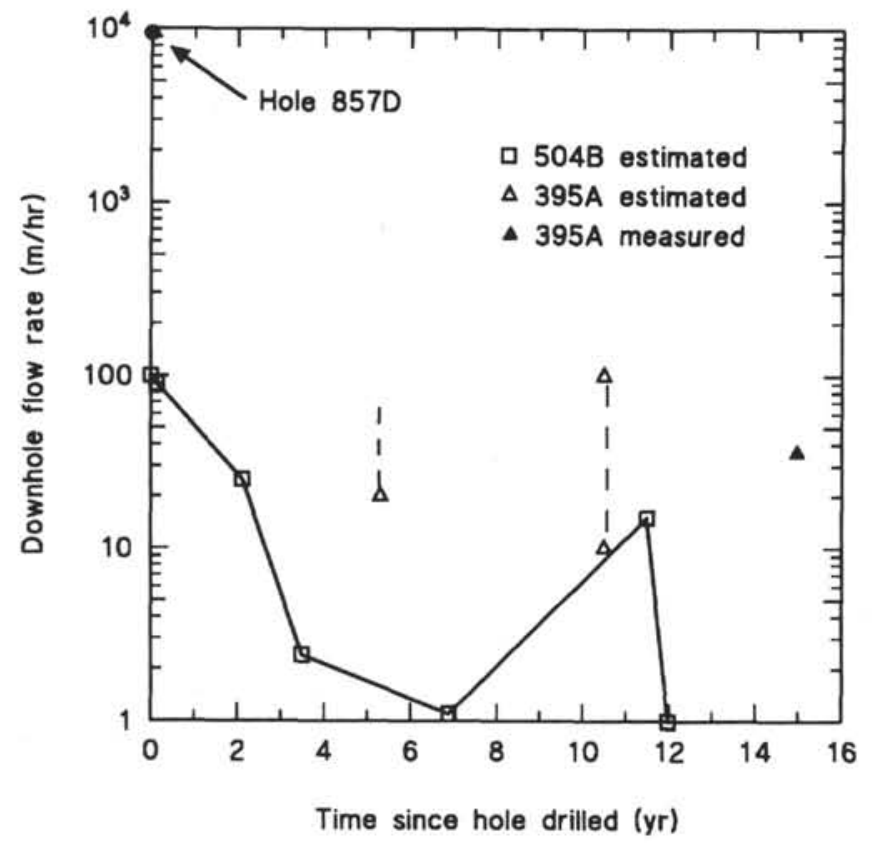

Figure 10. Comparison of downhole flow rate estimated in Hole 857D with rates estimated from temperature logs or directly measured in the two best documented cases of downhole flow into young, thinly sedimented oceanic crust. The time axis refers to time since the downhole flow started when the holes were first drilled. The flows down Holes $395 \mathrm{~A}$ and 504B have remained active because the holes have been left open since they were first drilled, whereas Hole 857D was sealed during Leg 139, stopping its downhole flow.

Table 1. Summary of calculations of apparent transmissivity $(T)$ and permeability $(k)$ of zone from 610-615 mbsf in Hole 857D.

\begin{tabular}{|c|c|c|c|c|}
\hline \multicolumn{2}{|c|}{ Injection rate } & \multirow{2}{*}{$\begin{array}{c}\Delta \mathrm{P} \\
(\mathrm{MPa})\end{array}$} & \multirow{2}{*}{$\begin{array}{c}T \\
\left(10^{-3} \mathrm{~m}^{2} / \mathrm{s}\right)\end{array}$} & \multirow{2}{*}{$\left(10^{-11} \mathrm{~m}^{2}\right)$} \\
\hline (spm) & $(\mathrm{L} / \mathrm{s})$ & & & \\
\hline 80 & 26.3 & 0.049 & 2.94 & 9.59 \\
\hline 100 & 32.8 & $0.0^{7}$ & & \\
\hline 140 & 46.0 & 0.128 & 1.97 & 6.42 \\
\hline
\end{tabular}

${ }^{\text {a }}$ Calculations were made using Glover's formula under the assumption that nearly all of the fluids pumped during the injection tests conducted with the packer set in casing was accepted by this zone.

b Permeabilities calculated using a viscosity of $1.67 \times 10^{-3}$ $\mathrm{Pa}-\mathrm{s}$, appropriate for the temperature of the injected fluids as measured by the downhole pressure gauge, $4^{\circ} \mathrm{C}$.

\section{Bulk Permeability of the Deeper Open-hole Section of Hole 857D}

Given the presence of such anomalously conductive zones in the upper part of the open-hole section of Hole 857D, it was impossible to assess the average permeability of the formation with the packer inflated in casing. However, the strong downhole flow kept temperatures considerably depressed throughout much of the hole, so that it was possible to run the packer deep in the hole without danger of it failing because of high temperatures. With the packer inflated in a thick sill below the conductive zones, the bulk permeability of a characteristic section of intercalated sills and sediments could be assessed.

A comparison of the downhole pressure records during packer inflation for both of the packer experiments in Hole 857D (Fig. 11) illustrates several important differences that are essential to understanding the records and interpreting the average formation permeability in Hole 857D. With the packer in casing above the conductive zone

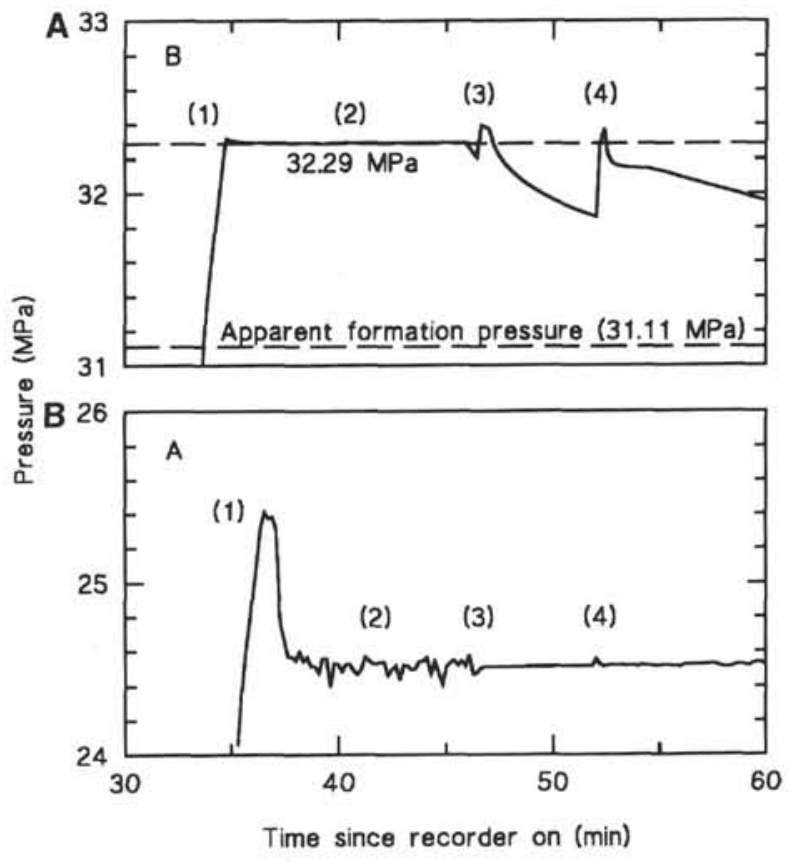

Figure 11. Detailed pressure records of the inflation procedures during the packer experiments in Hole 857D with the packer set at (A) $96 \mathrm{mbsf}$ in casing and (B) $756 \mathrm{mbsf}$ deep in the hole. In each case, a standard four-step procedure was followed, including (1) dropping the go-devil down the pipe to the uninflated packer; (2) waiting for about 10 minutes for a baseline reading of borehole pressure; (3) pressurizing the drill string for about $5 \mathrm{~min}$ to inflate the packer; and (4) shifting the packer control sleeve to lock the packer elements in the inflated position, while at the same time applying the residual pressure in the drill string to the isolated zone as a slug test. The differences between the two records are discussed in detail in the text.

at $610-615 \mathrm{mbsf}$ (Fig. 11A), the packer inflation procedure was dominated by the large downhole flow, which in effect "sucked" the packer into an inflated position well before any inflation pressure was applied from the rig floor. Thus, when the go-devil first landed in the packer ( $37 \mathrm{~min}$ ), the pressures registered on the recorder changed from cold hydrostatic to a lower, noisy value close to formation pressure, as the packer inadvertently sealed the hole early, but at a low effective inflation pressure. When the full inflation pressure was applied to the packer elements ( $46 \mathrm{~min}$ ), the pressure signal stabilized at a formation value. The difference between the cold hydrostatic and formation pressure is at least $0.9 \mathrm{MPa}$, but is probably larger because we did not get a good reading of the cold hydrostatic value. Finally, when the packer inflation sleeve was closed ( $52 \mathrm{~min}$ ), the slug test that normally occurs barely registered because the isolated zone is so transmissive.

In contrast, with the packer below the conductive zone, the inflation procedure was unaffected by downhole flow, and appeared much more typical (Fig. 11B). When the go-devil first landed (35 min), the packer remained uninflated and the recorder registered a stable cold hydrostatic borehole pressure baseline, as is normal procedure. When the inflation pressure was applied to the packer and held for $5 \mathrm{~min}$, (47-52 $\mathrm{min})$, recorded pressures began a smooth approach from the cold hydrostatic pressure in the borehole toward the formation value. When the inflation sleeve was closed $(52 \mathrm{~min})$, a slug test was indeed registered, although it was of somewhat irregular quality. Thus, the record of the ensuing test sequence is superposed on the smooth approach of the reference pressure from the borehole hydrostatic value toward the formation pressure, and the data processing required that the measured pressures first be corrected for the extrapolation of the decay curve monitored at 47-52 $\mathrm{min}$. We represented this decay curve as the Horner curve (described previously) appropriate for the case in which the borehole was held at a cold hydrostatic pressure 
different from formation pressure for the time period beginning when the section was drilled and ending when the packer was inflated. When the data recorded from $47-52 \mathrm{~min}$ were fit to such a function, they extrapolated to a formation pressure about 1.1-1.2 MPa less than the cold hydrostatic pressure (Fig. 11B). This is consistent with both the differential pressure measured when the instrumented borehole seal was installed and the hydrostatic pressure appropriate for the estimated undisturbed thermal state of the formation at this site (Davis and Becker, this volume).

As noted previously, the two slug tests required excessive pumped volumes to produce pressure pulses, and their decay curves are irregular such that the initial parts of these curves do not fit the type curves properly. Therefore, they were not processed to estimate permeability, but the better-behaved later parts of the decay curves were fit to the type curves in order to calculate a proper correction for the residual effects of these slug tests on the subsequent injection tests. Both injection tests nicely followed the prescribed linear relationships of pressure vs. In time during injection and pressure vs. the Horner function during subsequent shut in (Fig. 12). The slopes of these linear relationships yielded reasonably consistent determinations of a transmissivity on the order of $1-2 \times 10^{-5} \mathrm{~m}^{2} / \mathrm{s}$ and a bulk permeability on the order of $10^{-14} \mathrm{~m}^{2}$ for the lower $180 \mathrm{~m}$ of Hole 857D (Table 2). This permeability value can perhaps be taken as a representative average value for the intercalated sediment/sill sequence where it is not disrupted by unusually conductive zones like that at $610-615 \mathrm{mbsf}$. However, there are almost certainly significant variations of permeability within the sediment/sill sequence, and this bulk permeability value does not preclude the existence of discrete conductive zones within the lower $180 \mathrm{~m}$ of the hole. Nevertheless, the fact that the transmissivity of this section is two orders of magnitude less than the transmissivity of the upper section of open hole would require that any such discrete zones be much narrower and/or orders of magnitude less permeable than the highly conductive zone at 610-615 mbsf.

\section{Bulk Permeability of Igneous Basement in Hole 858G}

Site 858 was located in an active vent field in sediments overlying a basement high, suggesting that there must be significant permeability in the basement section. As noted previously, the open-hole section of Hole $858 \mathrm{G}$ includes $162.6 \mathrm{~m}$ of igneous basement; although core recovery was poor, the log data indicate that this section comprises an apparently continuous sequence of basaltic units (Langseth and Becker, this volume). The purpose of the packer and flowmeter measurements was to determine the permeability structure of this section and compare the results to permeabilities measured in other holes that penetrate young upper oceanic crust in thinly sedimented settings.

As discussed previously, the last three injection tests of the sequence of standard packer tests (Fig. 8) may have resulted in inadvertent hydrofracture and were therefore flawed as permeability measurements. The first two slug tests and the first injection test (conducted

Table 2. Summary of the calculations of transmissivity $(T)$ and average permeability $(k)$ for the lower $180 \mathrm{~m}$ of Hole 857D.

\begin{tabular}{|c|c|c|c|}
\hline \multicolumn{2}{|c|}{ Injection rate } & \multirow{2}{*}{$\begin{array}{c}{ }^{T} \\
\left(10^{-5} \mathrm{~m}^{2} / \mathrm{s}\right)\end{array}$} & \multirow{2}{*}{$\left(10^{-14} \mathrm{~m}^{2}\right.$} \\
\hline (spm) & $(\mathrm{L} / \mathrm{s})$ & & \\
\hline & & & \\
\hline 0 (shut & $t$ ir & & \\
\hline & 5. & 1.4 & \\
\hline 0 (shut & tin) & $\begin{array}{l}2.17 \\
\text {. }\end{array}$ & $\begin{array}{l}1.63 \\
\text { S }\end{array}$ \\
\hline
\end{tabular}

${ }^{\text {a }}$ Calculations are from the two injection tests conducted with the packer set at 756 mbsf (Figs. 7 and 12).

b Permeabilities calculated using a viscosity of $1.39 \times 10^{-3}$ $\mathrm{Pa}-\mathrm{s}$, appropriate for the mean temperature of the injected fluids throughout the isolated zone as estimated by the downhole pressure gauge, about $10^{\circ} \mathrm{C}$.
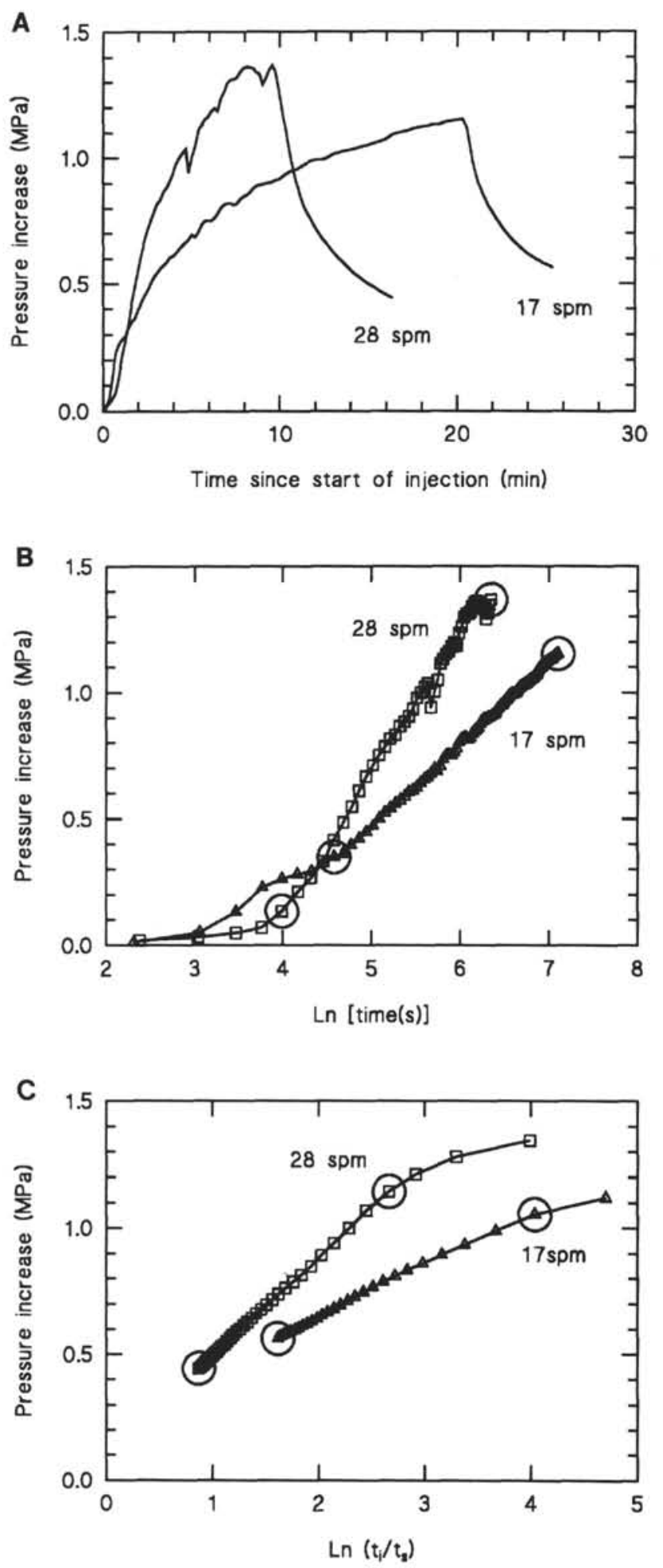

Figure 12. Results of processing the two injection tests conducted in Hole 857D with the packer set at $756 \mathrm{mbsf}$, isolating the deepest $180 \mathrm{~m}$ of the hole. A. Pressures corrected for the slow decay of measured values from cold hydrostatic pressure in the borehole toward the formation value after the packer was inflated. B. Rise of corrected pressures during injection vs, the log of time since injection was started. C. Decay of corrected pressures in the shut-in hole after injection was ended. For both Figs. 12B and 12C, the circled points denote the end points of the linear segments of these curves; slopes of these linear segments were obtained by linear regression and were used in the calculation of the transmissivities and permeabilities reported in Table 2. 
Table 3. Summary of the calculations of transmissivity $(T)$ and average permeability $(k)$ of the open-hole section of Hole 858G. ${ }^{\mathrm{a}}$

\begin{tabular}{|c|c|c|c|c|c|c|}
\hline \multirow[b]{2}{*}{ Test } & \multirow[b]{2}{*}{$\alpha$} & \multirow{2}{*}{$\begin{array}{l}t_{1}^{b} \\
(s)\end{array}$} & \multicolumn{2}{|c|}{ Injection rate } & \multirow{2}{*}{$\begin{array}{c}T \\
\left(10^{-5} \mathrm{~m}^{2} / \mathrm{s}\right)\end{array}$} & \multirow{2}{*}{$\left(10^{-14} \mathrm{~m}^{2}\right)$} \\
\hline & & & (spm) & $(\mathrm{L} / \mathrm{s})$ & & \\
\hline Slug \#1 & 0.01 & 105 & - & - & 2.50 & $1.66^{\mathrm{c}}$ \\
\hline Slug \#2 & 0.01 & 45 & - & - & 5.87 & $3.84^{\mathrm{c}}$ \\
\hline Injection $\# 1 \mathrm{a}^{\mathrm{d}}$ & - & - & 15 & 4.9 & 2.70 & $2.25^{\mathrm{e}}$ \\
\hline Injection \#1 & - & - & 30 & 9.8 & 2.78 & $2.32^{\mathrm{e}}$ \\
\hline Shut in & - & - & 0 & 0 & 2.83 & $2.36^{\circ}$ \\
\hline
\end{tabular}

"Calculations are from the slug tests and first injection test conducted with the packer inflated in casing (Figs. 8, 13, and 14).

${ }^{b}$ For a slug test, the parameter $t_{l}$ corresponds to the amount (in seconds) that the type curve was shifted to produce the best fit to the data; $T$ and $k$ are calculated from $t_{l}$ by the equations $T=V_{w} C_{u} \rho_{u} g / \pi t$, and $k=\mu V_{w} C_{u} / \pi b t_{i}$.

c Permeabilities calculated using the compressibility determined from the volume pumped to produce the pressure rise of slug test \#2, and a viscosity of $1.09 \times 10^{-3} \mathrm{~Pa}-\mathrm{s}$ appropriate for an estimated mean temperature of $20^{\circ} \mathrm{C}$ in the tested interval.

${ }^{d}$ As explained in the text, injection tests \#1a and \#1b are the two segments of the first injection test, during which the injection rate was started at 15 spm but increased to $30 \mathrm{spm}$ when there was no pressure increase observed on the rig floor gauges.

e Permeabilities calculated using a viscosity of $1.39 \times 10^{-3} \mathrm{~Pa}-\mathrm{s}$ appropriate for the mean temperature of the injected fluids throughout the isolated zone as estimated by the downhole pressure gauge, about $10^{\circ} \mathrm{C}$.

at the lowest injection rate) were processed by the methods described previously to estimate the transmissivity and bulk permeability of the basement section penetrated by Hole $858 \mathrm{G}$. The "first" injection test, labeled $30 \mathrm{spm}$, actually includes an initial $5 \mathrm{~min}$ of injection at only $15 \mathrm{spm}$; when this produced no pressure increase on the rig floor gauges, the injection rate was increased to $30 \mathrm{spm}$, resulting in the shoulder seen in the pressures recorded downhole. This was processed as two injection tests, with a shut-in period following the second. The time origin for the second phase at $30 \mathrm{spm}$ was taken to be about $26 \mathrm{~s}$ (three data-sampling periods of the GRC recorder) before the pump rate was actually increased to $30 \mathrm{spm}$, consistent with the steep initial rises of pressure observed whenever injection was begun during the sequence. The curve fits and permeability calculations are summarized in Figs. 13 and 14 and Table 3. With the exception of the poorest fit (for Slug test \#2), the results are all consistent with a transmissivity of $2-3 \times 10^{-5} \mathrm{~m}^{2} / \mathrm{s}$ for the entire interval. This is equivalent to an average permeability of about $2 \times 10^{-14} \mathrm{~m}^{2}$. This value is quite consistent with values measured previously in the upper levels of oceanic basement in more thinly sedimented settings and with the value obtained for the sill/sediment sequence deep in Hole 857D.

As noted previously, the flowmeter experiment in Hole $858 \mathrm{G}$ had to be conducted at lower injection rates than in Hole 857D, because the basement in Hole $858 \mathrm{G}$ would not accept the pumped fluids as rapidly and the back pressures resulted in fluid leakage at the rig floor seal around the logging cable. This is consistent with the difference in transmissivities calculated for the entire open-hole sections of the two holes, about two orders of magnitude. At the low injection rates, the lack of a wireline heave compensator resulted in poor resolution by the flowmeter, and the data do not justify calculation of a permeability $\log$. Although there is a general decrease in flow readings from the bottom of casing to $330 \mathrm{mbsf}$, these readings are inversely proportional to hole size, suggesting that the latter (not formation permeability) is the most important factor affecting the response of the flowmeter in this section.

Nevertheless, the sharp decrease in flowmeter readings below 330 mbsf (Fig. 9) suggests the existence of at least one hydraulically conductive zone in the section between 340 and 350 mbsf. Ironically, this zone appears to be immediately below the deepest point logged with the resistivity tool (or any other logging tool other than temperature). The resistivity log shows two sections with low values, at about 320 and 335 mbsf, which by analogy with the results in Hole 857D might be suggested as other conductive zones, although the flowmeter re-
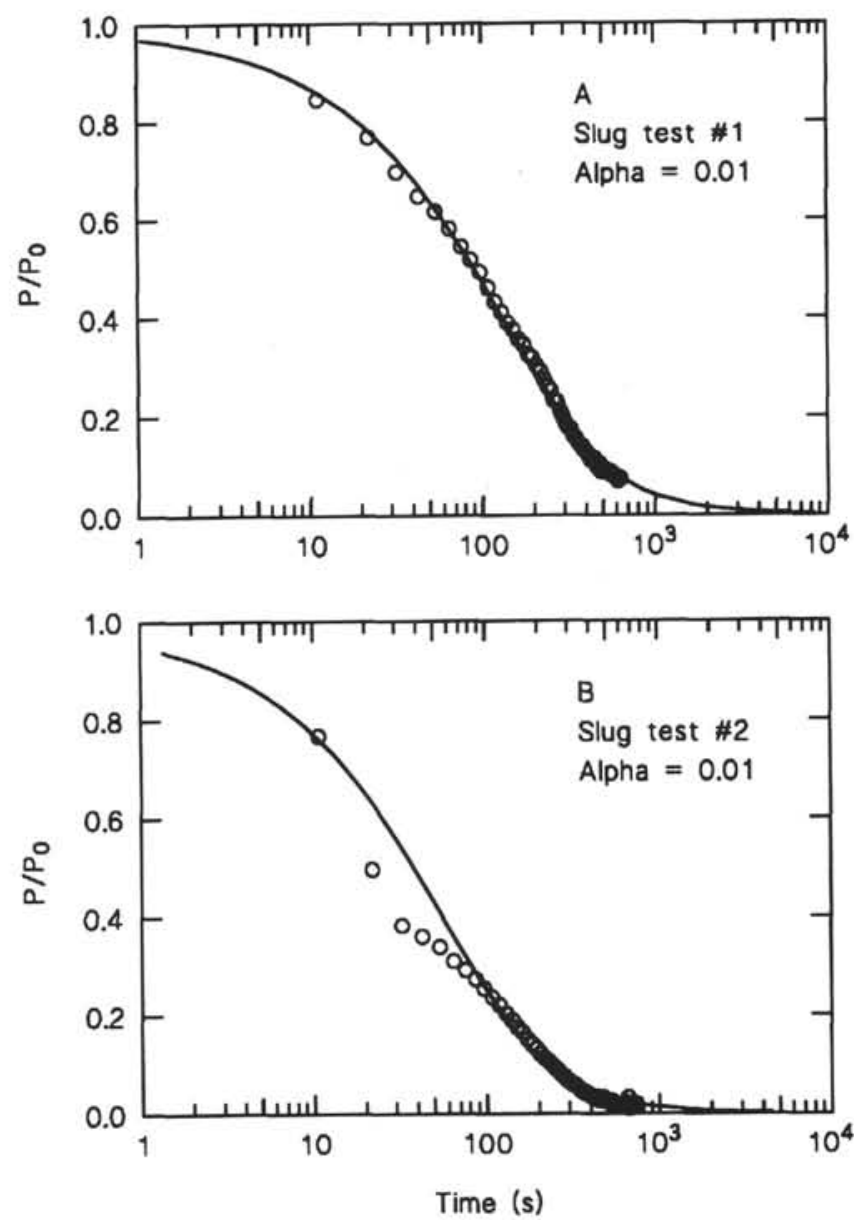

Figure 13. Best fits of measured data (circles) to the type curves of Cooper et al. (1967) of the pressures recorded during the two slug tests conducted in Hole $858 \mathrm{G}$ with the packer inflated in casing, isolating the upper $162.6 \mathrm{~m}$ of basement.

cord does not show any clear indications of flow into these zones. In fact, a temperature log measured between the first and second packer inflations shows a change in slope at about $330 \mathrm{mbsf}$, with a steep gradient below and a more nearly isothermal gradient above (Shipboard Scientific Party, 1992b). This suggested that the section between 320 and 350 mbsf was drawing ocean bottom water down Hole $858 \mathrm{G}$, but the flowmeter showed no indication of downhole flow when the packer was deflated, so the rate of any downhole flow could only have been much lower than that at which bottom water was flowing down Hole 857D. If the debatable assumption is made that most of the transmissivity detected in Hole $858 \mathrm{G}$ is concentrated in the three zones between 320 and 350 mbsf, with a total thickness of about $10-15 \mathrm{~m}$, then the resulting average permeability of these zones would be on the order of $2-3 \times 10^{-13} \mathrm{~m}^{2}$. This is several orders of magnitude lower than the analogous calculated permeability for the exceptionally conductive zone in Hole 857D.

\section{DISCUSSION AND CONCLUSIONS}

The permeability values obtained in Holes $857 \mathrm{D}$ and $858 \mathrm{G}$ are summarized in Fig. 15. The results indicate that there are at least two hydrogeological types of formations in the Middle Valley hydrothermal system: (1) relatively thin, highly conductive zones such as that encountered in the upper part of the open-hole section in Hole 857D and (2) thicker sections of representative basement, whether it be true igneous basement as at Hole $858 \mathrm{G}$ or a sediment/sill sequence as at Hole $857 \mathrm{D}$, with typical average permeabilities on the order of $10^{-14}$ 

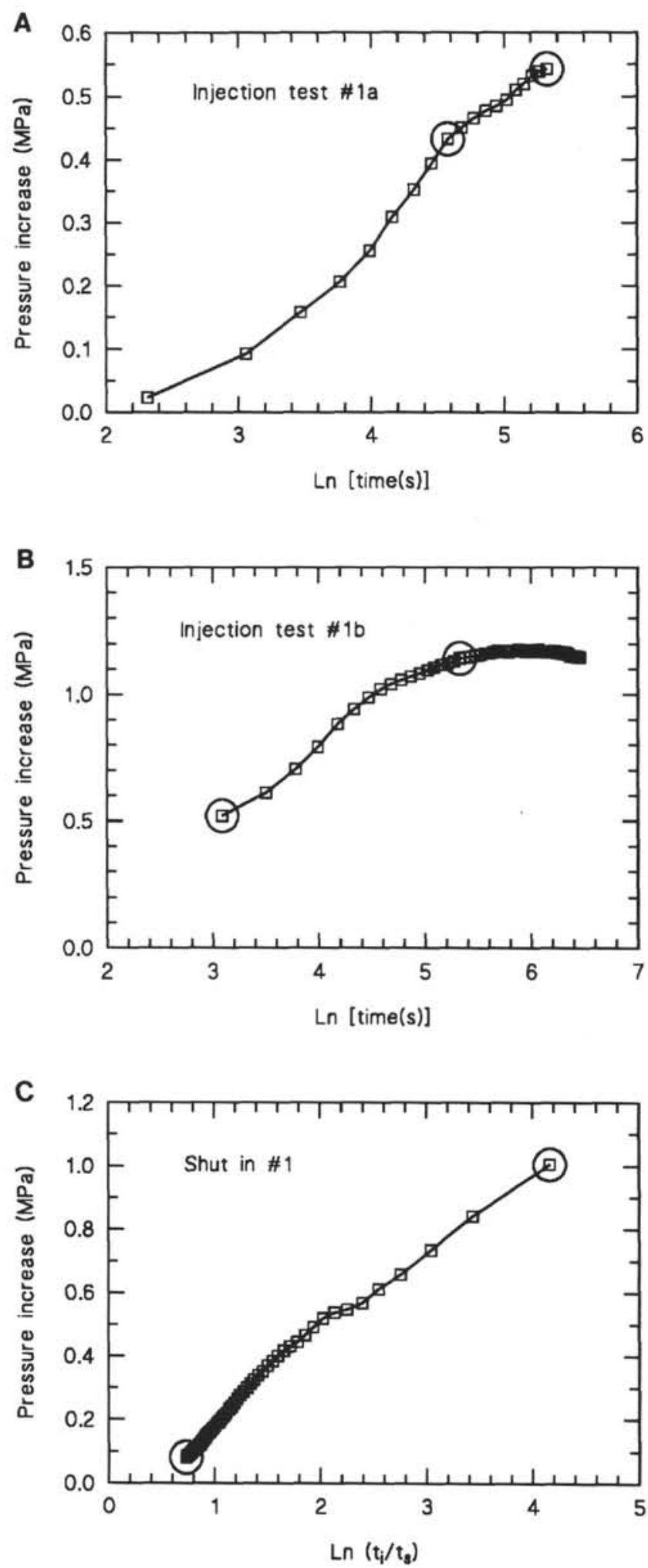

Figure 14. Results of processing the first injection test conducted in Hole 858G with the packer set in casing, isolating the upper $162.6 \mathrm{~m}$ of basement. A. Rise of pressures during injection vs. the log of time since injection was started, for the initial phase of injection at $15 \mathrm{spm}$. B. Rise of pressures during injection vs. the log of time since injection was started, for the second phase of injection at $30 \mathrm{spm}$. C. Decay of corrected pressures in the shut-in hole after injection was ended. For all three plots, the circled points denote the end points of the linear segments of these curves; slopes of these linear segments were obtained by linear regression and were used in the calculation of the transmissivities and permeabilities reported in Table 3.

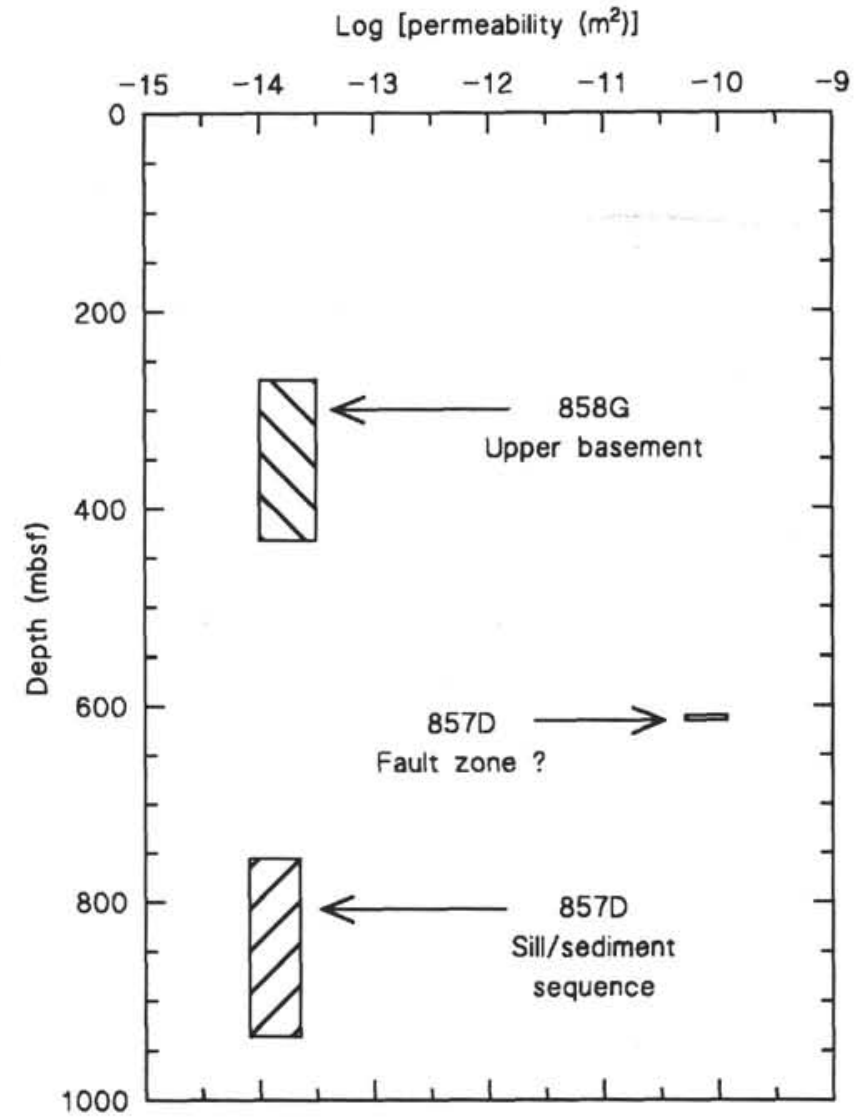

Figure 15. Permeabilities measured in Holes $857 \mathrm{D}$ and $858 \mathrm{G}$ vs. depth below seafloor. The vertical extent of each rectangle represents the vertical interval over which average permeability was measured; the horizontal extent represents the estimated error range in the permeability value.

$\mathrm{m}^{2}$. Of course, there is at least one other important hydrogeological type of formation at Middle Valley: the thick sections of sediments that overlie the basement. The permeabilities of representative samples of the sediments measured in the laboratory by Fisher et al. (this volume) were typically on the order of $10^{-16} \mathrm{~m}^{2}$, two orders of magnitude less than the basement permeabilities obtained herein.

The average permeabilities of representative basement in both Holes 857D and 858G are quite consistent with those measured in upper levels of oceanic basement in three DSDP/ODP holes that penetrate young off-axis crust formed at unsedimented ridges (Fig. 16). Numerical modeling (e.g., Fehn et al., 1983; Fisher et al., 1990) has indicated that such permeabilities are sufficient to support hydrothermal convection in off-axis settings, where the thermal driving forces for convection are much less than at spreading centers. Therefore, given the large thermal driving forces at the Middle Valley sedimented spreading center, the average permeabilities for the representative sections of Hole 857D and 858G are certainly sufficient to support vigorous hydrothermal convection, even if there were no zones of exceptionally high hydraulic conductivity such as encountered in the upper open-hole section of Hole 857D.

The presence of such highly transmissive zones must have a profound effect on the circulation system. The transmissivity and apparent permeability of the single zone at $610-615 \mathrm{mbsf}$ in Hole 857D are orders of magnitude greater than the transmissivities and average permeabilities of the deepest $180 \mathrm{~m}$ of that hole or the $162 \mathrm{~m}$ of igneous basement in Hole $858 \mathrm{G}$. Therefore, if there is any lateral or vertical extent to this zone, it must act as an important conduit to focus large hydrothermal fluxes. As there was virtually no core recovery in this zone, there were no direct indications as to why this formation is so transmissive. However, considerable circumstantial evi- 


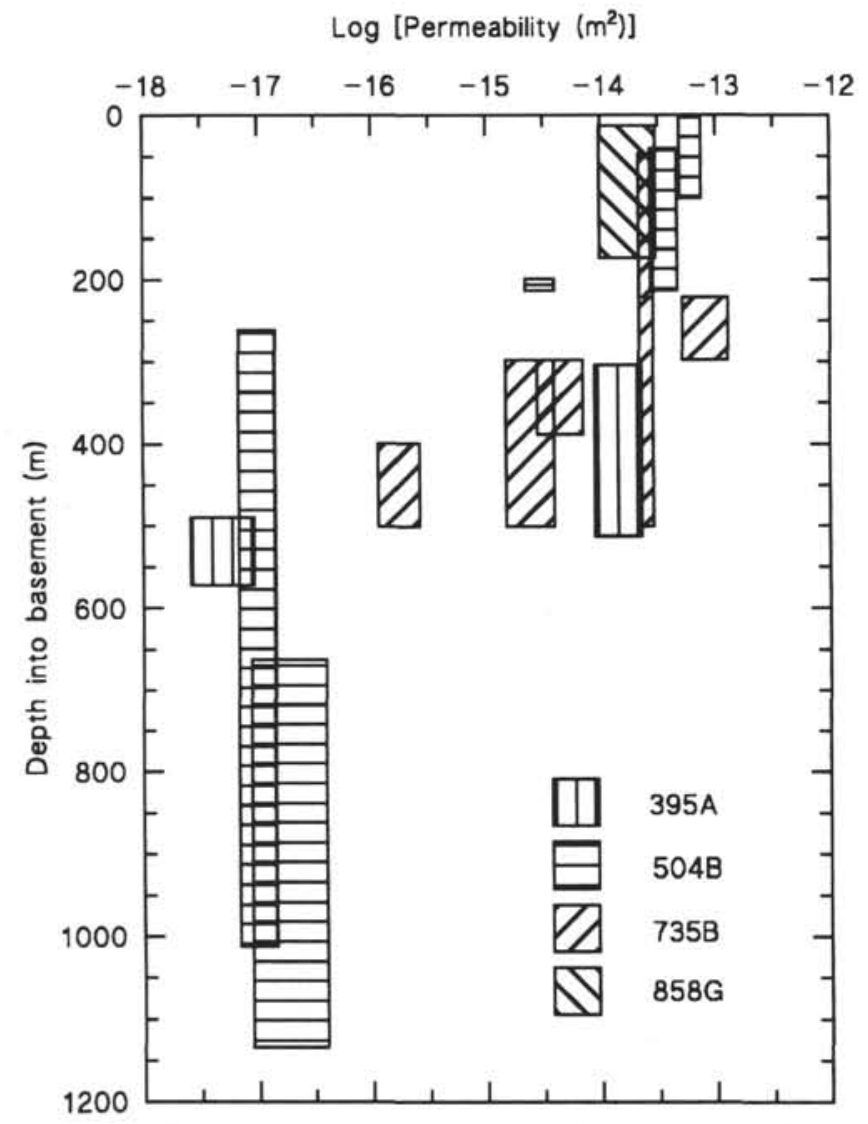

Figure 16. Comparison of the permeability measured in the upper part of igneous basement in Hole $858 \mathrm{G}$ with previous results in young oceanic crust. Results are plotted against depth into igneous basement, which could not be clearly determined for Hole 857D, so the values from Hole 857D are not shown.

dence suggests that a major fault zone was intersected by the hole. Seismic data clearly indicate the presence of normal faults in the region (Davis and Villinger, 1992; Rohr and Schmidt, this volume). Seafloor surveys indicate that one such axis-parallel fault outcrops on the seafloor within a few hundred $m$ west of both Sites 857 and 858 (Shipboard Scientific Party, 1992a, 1992b). Furthermore, downhole logs indicate that there is a significant depth offset between correlatable units in the sediment sections at both sites (Langseth and Becker, this volume).

Thus, it appears to be a reasonable interpretation that Hole 857D intersected a fault zone. If so, our measurements represent the first direct determination of the characteristic hydrogeological properties associated with the kind of fault or large-scale fracture system that has long been surmised to control circulation patterns at axial hydrothermal systems, whether sedimented or unsedimented. Even if it is not the case that the zone at $610-615 \mathrm{mbsf}$ in Hole 857D is the fault zone that outcrops between Sites 857 and 858 , the transmissivity measured in this zone strongly confirms the inference that discrete, irregular zones of high hydraulic conductivity must dominate circulation patterns in axial hydrothermal systems. It will be difficult to understand and model the physical processes in axial hydrothermal systems unless methods are developed to map the three-dimensional distributions of such zones and assess their hydrogeological properties.

\section{ACKNOWLEDGMENTS}

The permeability measurements reported here would not have been possible without the expertise and hard work of the SEDCO core technicians, J. Attryde and P. Esteves, and the SEDCO drill crew under the supervision of the drilling superintendent, K. Horne. We also acknowledge the fine work of the ODP special tools engineer, T. Pettigrew, who developed the go-devil that enabled the flowmeter to be run with the packer. This report was improved after careful reviews by C. Forster, G. Bohling, and J.J. Butler, Jr. This study was supported by NSF grants OCE- 8800077 and OCE-9017861. GSC Cont. No. 25093 .

\section{REFERENCES*}

Anderson, R.N., and Zoback, M.D., 1982. Permeability, underpressures, and convection in the oceanic crust near the Costa Rica Rift, eastern equatorial Pacific. J. Geophys. Res., 87:2860-2868.

Anderson, R.N., Zoback, M.D., Hickman, S.H., and Newmark, R.L., 1985. Permeability vs. depth in the upper oceanic crust: in situ measurements in DSDP Hole 504B, eastern equatorial Pacific. J. Geophys. Res., 90:36593669.

Becker, K., 1986. Special report: development and use of packers in ODP. JOIDES J., 12:51-57.

, 1988. A guide to ODP tools for downhole measurements. ODP Tech. Notes, 10.

- 1989. Measurements of the permeability of the sheeted dikes in Hole 504B, ODP Leg 111. In Becker, K., Sakai, H., et al., Proc. ODP, Sci. Results, 111: College Station, TX (Ocean Drilling Program), 317-325.

, 1990. Measurements of the permeability of the upper oceanic crust at Hole 395A, ODP Leg 109. In Detrick, R., Honnorez, J., Bryan, W.B., Juteau, T., et al., Proc. ODP, Sci. Results, 106/109: College Station, TX (Ocean Drilling Program), 213-222.

- 1991. In-situ bulk permeability of oceanic gabbros in Hole 735B, ODP Leg 118. In Von Herzen, R.P., Robinson, P.T., et al., Proc. ODP, Sci. Results, 118: College Station, TX (Ocean Drilling Program), 333-347.

Becker, K., Foss, G., et al., 1992. Proc. ODP, Init. Repts., 137: College Station, TX (Ocean Drilling Program).

Becker, K., Langseth, M.G., Hyndman, R.D., 1984. Temperature measurements in Hole 395B, Leg 78B. In Hyndman, R.D., and Salisbury, M.H., et al., Init. Repts. DSDP, 78B: Washington (U.S. Govt. Printing Office), 689-698.

Becker, K., Langseth, M.G., Von Herzen, R.P., and Anderson, R.N., 1983. Deep crustal geothermal measurements, Hole 504B, Costa Rica Rift. J. Geophys. Res., 88:3447-3457.

Bredehoeft, J.D., and Papadopulos, S.S., 1980. A method for determining the hydraulic properties of tight formations. Water Resour. Res., 16:223-238.

Cooper, H.H., and Jacob, C.E., 1946. A generalized graphical method for evaluating formation constants and summarizing well-field history. Eos, 27:526-534.

Cooper, H.H., Jr., Bredehoeft, J.D., and Papadopulos, I.S., 1967. Response of a finite diameter well to an instantaneous charge of water. Water Resour. Res., 3:267-269.

Coyle, B.J., and Zoback, M.D., 1988. In situ permeability and fluid pressure measurements at $\sim 2 \mathrm{~km}$ depth in the Cajon Pass research well. Geophys. Res. Lett., 15:1029-1032.

Curray, J.R., Moore, D.G., et al., 1982. Init. Repts. DSDP, 64: Washington (U.S. Govt. Printing Office).

Davis, E.E., Becker, K., Pettigrew, T., Carson, B., and MacDonald, R., 1992. CORK: a hydrologic seal and downhole observatory for deep-ocean boreholes. In Davis, E.E., Mottl, M.J., Fisher, A.T., et al., Proc. ODP, Init. Repts., 139: College Station, TX (Ocean Drilling Program), 43-53.

Davis, E.E., and Villinger, H., 1992. Tectonic and thermal structure of the Middle Valley sedimented rift, northern Juan de Fuca Ridge. In Davis, E.E., Mottl, M.J., Fisher, A.T., et al., Proc. ODP, Init. Repts., 139: College Station, TX (Ocean Drilling Program), 9-41.

Fehn, U., Green, K.E., Von Herzen, R.P., and Cathles, L.M., 1983. Numerical models for the hydrothermal field at the Galapagos spreading center. $J$. Geophys. Res., 88:1033-1048.

Fisher, A.T., Becker, K., Narasimhan, T.N., Langseth, M.G., and Mottl, M.J., 1990. Passive, off-axis convection through the southern flank of the Costa Rica rift. J. Geophys. Res., 95:9343-9370.

Gartling, D.K., 1977. Convective heat transfer analysis by the finite element method. Comput. Methods Appl. Mech. Eng., 12:365-382.

\footnotetext{
- Abbreviations for names of organizations and publications in ODP reference lists follow the style given in Chemical Abstracts Service Source Index (published by American Chemical Society).
} 
Hess, K.M., 1989. Use of a borehole flowmeter to determine spatial heterogeneity of hydraulic conductivity and macrodispersion in a sand and gravel aquifer, Cape Cod, Massachusetts, Proc. Conf. on New Field Techniques for Quantifying the Physical and Chemical Properties of Heterogeneous Aquifers. National Water Well Assoc., Dallas, TX, 497-508.

Hickman, S.H., Langseth, M.G., and Svitek, J.F., 1984. In situ permeability and pore-pressure measurements near the mid-Atlantic Ridge, Deep Sea Drilling Project Hole 395A. In Hyndman, R.D., Salisbury, M.H., et al., Init. Repts. DSDP, 78 (Pt. 2): Washington (U.S. Govt. Printing Office), 699-708.

Hickman, S.H., and Zoback, M.D., 1983. The interpretation of hydraulic fracturing pressure-time data for in-situ stress determination. Hydraulic Fracturing Stress Measurements: Washington (National Academy Press), $44-54$.

Horner, D.R., 1951. Pressure build-up in wells. Proc. Third World Pet. Congr., 2:501.

Hufschmied, P., 1984. Hydrogeologie emmental, teil IV, modellstudie zur bestimmung des grundwasser-dargebotes im testgeviet emmental, Wasseru. Energiewirtschaftsamt des Kantons Bern.

Kopietz, J., Becker, K., and Hamano, Y., 1990. Temperature measurements at Site 395, ODP Leg 109. In Detrick, R., Honnorez, J., Bryan, W.B., Juteau, T., et al., Proc. ODP, Sci. Results, 106/109: College Station, TX (Ocean Drilling Program), 197-203.

Matthews, C.S., and Russell, D.G., 1967. Pressure Build-up and Flow Tests in Wells. Soc. Pet. Eng., AIME, Monogr. 1.

Molz, F.J., Morin, R.H., Hess, A.E., Melville, J.G., and Guven, O., 1989. The impeller meter for measuring aquifer permeability variations: evaluation and comparison with other tests. Water Resour. Res., 25:1677-1683.
Morin, R.H., Hess, A.E., and Becker, K., 1992. In situ measurements of fluid flow in DSDP Holes 395A and 534A: results from the DIANAUT program. Geophys. Res. Lett., 19:509-512.

Morin, R.H., Hess, A.E., and Paillet, F.L., 1988. Determining the distribution of hydraulic conductivity in a fractured limestone aquifer by simultaneous injection and geophysical logging. Ground Water, 26:587-595.

Neuzil, C.E., 1982. On conducting the modified "slug" test in tight formations. Water Resour. Res., 18:439-441.

Papadopulos, S.S., Bredehoeft, J.D., and Cooper, H.H., 1973. On the analysis of "slug test" data. Water Resour. Res., 9:1087-1089.

Parsons, R.W., 1966. Permeability of idealized fractured rock. Soc. Pet. Eng. J., 6:126-136.

Shipboard Scientific Party, 1992a. Site 857. In Davis, E.E., Mottl, M.J., Fisher, A.T., et al., Proc. ODP, Init. Repts., 139: College Station, TX (Ocean Drilling Program), 283-429.

, 1992b. Site 858. In Davis, E.E., Mottl, M.J., Fisher, A.T., et al., Proc. ODP, Init. Repts., 139: College Station, TX (Ocean Drilling Program), 431-569.

Snow, D.T., 1968. Rock fracture spacing, openings and porosities. J. Soil Mech. Found. Div., Am. Soc. Civ. Eng. Proc., 94.

Sverdrup, H.U., Johnson, M.W., and Fleming, R. (Eds.), 1942. The Oceans: Their Physics, Chemistry and General Biology: Englewood Cliffs, NJ (Prentice-Hall).

Date of initial receipt: 12 January 1993

Date of acceptance: 30 July 1993

Ms 139SR-252 